\title{
Integration of Major QTLs of Important Agronomic Traits in Soybean
}

\author{
Guohua Hu, Qingshan Chen, Chunyan Liu, \\ Hongwei Jiang, Jialin Wang and Zhaoming Qi \\ Northeast Agricultural University, \\ Land Reclamation Research \& Breeding Centre of Heilongjiang \\ P. R. China
}

\section{Introduction}

Soybean [Glycine max (L.) Merr.] is one of the most important crops in the world, accounting for $48 \%$ of the world market in oil crops, and is used mostly for animal feed and for oil production. In soybean, most agronomic traits, such as abiotic stress, biological stress, protein concentration, oil content and yield, are quantitative traits controlled by multiple genes. Moreover, genotypic expression of the phenotype is environmentally dependent, which affected QTLs detection greatly. QTLs detection was also affected by marker sets, experimental design, mapping populations, and statistical methods, which result in the location of QTLs mapped by the same marker differently.

From the first publication of quantitative trait locus (QTL) of soybean using molecular markers (Paterson et al. 1988), numerous QTLs underlying different traits of soybean have been identified in different genetic backgrounds and environments. However, few identical QTLs were identified in same experimental population or same environment by different researchers or in different years (Orf 1999; Mansur 1993, 1996). All of these interfered in QTLs to improve oil content of soybean by marker-assisted selection (MAS). Integrated QTL analysis can facilitate the identification of "real" QTL and has attracted a great deal of attention.

Recently, the International Maize and Wheat Improvement Center put forward a proposal to find universal QTLs by building a consensus map. This proposal offers a basis for QTL analysis and marker-assisted selection (MAS). Meta-analysis method led to about twofold increase in precision in the estimates of QTL position compared to the most precise initial QTL position within the corresponding region.

In this chapter, QTL meta-analysis for major agronomic traits in soybean was performed for the first time. Published QTLs were collected, a consensus map of published maps with a reference map was created, consensus QTLs were acquired by the meta-analysis approach, genes were mined using bioinformatics tools, and markers of consensus QTLs with high effects and small CIs were provided for MAS. 


\section{Collection of important agronomic traits QTLs}

\subsection{Collection of seed quality QTLs}

\subsubsection{Oil content QTLs}

Oil and protein concentration account for about $60 \%$ of dry soybeans by weight, protein at $40 \%$ and oil at $20 \%$. The 130 QTLs for soybean oil content published in the last 20 years were

\begin{tabular}{|c|c|c|c|c|c|c|}
\hline $\begin{array}{l}\text { No. of } \\
\text { QTL }\end{array}$ & Parent 1 & Parent 2 & $\begin{array}{c}\text { Population } \\
\text { Size }\end{array}$ & $\begin{array}{c}\text { Analysis } \\
\text { Method }\end{array}$ & \begin{tabular}{|c|}
$\begin{array}{c}\text { Population } \\
\text { type }\end{array}$ \\
\end{tabular} & Reference \\
\hline 11 & Charleston & $\begin{array}{c}\text { Dong } \\
\text { nong594 }\end{array}$ & 154 & $\begin{array}{l}\text { CIM } \\
\text { MIM }\end{array}$ & RIL & Shan,2008 \\
\hline 10 & \begin{tabular}{|c|} 
Zhong Dou \\
29
\end{tabular} & $\begin{array}{l}\text { Zhong Dou } \\
32\end{array}$ & 255 & CIM & RIL & Wang,2008 \\
\hline 4 & Charleston & $\begin{array}{c}\text { Dong } \\
\text { nong594 }\end{array}$ & 154 & CIM & RIL & Chen,2007 \\
\hline 2 & $\begin{array}{c}01-042 \\
(\text { G.max })\end{array}$ & $\begin{array}{c}\text { KT- } \\
156(\text { G.soja })\end{array}$ & 120 & CIM & $\mathrm{F}_{2}$ & Zhang,2008 \\
\hline 1 & Wan 82-178 & $\begin{array}{l}\text { Tong Shan } \\
\text { Bo Pi }\end{array}$ & 133 & CIM & RIL & $\mathrm{Xu}, 2007$ \\
\hline 3 & He Feng 25 & Xin Min 6 & 122 & CIM & RIL & $\mathrm{Lv}, 2006$ \\
\hline 2 & Ke Xin 3 & $\begin{array}{c}\text { Zhong } \\
\text { Huang } 20\end{array}$ & 192 & CIM & $\mathrm{F}_{4}$ & Zhu,2006 \\
\hline 2 & Sui Nong 14 & Sui Nong 20 & 94 & CIM & $\mathrm{F}_{2}$ & Zhu,2006 \\
\hline 4 & Jin 23 & Hui Bu-Zhi & 474 & CIM & RIL & Liang,2005 \\
\hline 3 & N87-984-16 & TN93-99 & 101 & ANOVA & RIL & Panthee,2005 \\
\hline 3 & BSR 101 & LG82-8379 & 167 & ANOVA & RIL & Kabelka,2004 \\
\hline 6 & Essex & Williams & 131 & CIM & RIL & Hyten,2004 \\
\hline 4 & Wan 82-178 & $\begin{array}{c}\text { Tong Shan } \\
\text { Bo Pi }\end{array}$ & 133 & CIM & RIL & Li,2004 \\
\hline 4 & Charleston & $\begin{array}{c}\text { Dong } \\
\text { nong594 }\end{array}$ & 154 & CIM & RIL & Zhang ZC,2004 \\
\hline 3 & Zheng 92116 & Shang 951099 & 105 & IM & $\mathrm{F}_{2: 3}$ & Yang,2004 \\
\hline 1 & Ke Feng 1 & $\begin{array}{c}\text { Nan } \\
\text { Nong1138-2 }\end{array}$ & 184 & CIM & RIL & Zhang WK,2004 \\
\hline 1 & A3733 & PI437088A & 76 & ANOVA & RIL & Chung,2003 \\
\hline 3 & Ke Feng 1 & $\begin{array}{c}\text { Nan } \\
\text { Nong1138-2 }\end{array}$ & 201 & CIM & RIL & Wang,2001 \\
\hline 2 & Ke Feng 1 & $\begin{array}{c}\text { Nan } \\
\text { Nong1138-2 } \\
\end{array}$ & 201 & IM & RIL & $\mathrm{Wu}, 2001$ \\
\hline 3 & Ma.Belle & Proto & 82 & ANOVA & $\mathrm{F}_{2}$ & Csanadi,2001 \\
\hline 5 & Minsoy & Noir 1 & 236 & ANOVA & RIL & Specht,2001 \\
\hline 1 & A81-356022 & PI468916 & 98 & IM & $\mathrm{BC}_{3} \mathrm{~F}_{4}$ & Sebolt,2000 \\
\hline 1 & Parker & PI468916 & 100 & IM & $\mathrm{BC}_{3} \mathrm{~F}_{4}$ & Sebolt,2000 \\
\hline 2 & Archer & Minsoy & 233 & IM & RIL & Orf,1999 \\
\hline 3 & Archer & Noir 1 & 240 & IM & RIL & Orf,1999 \\
\hline 1 & Essex & Peking & 200 & ANOVA & $\mathrm{F}_{2: 3}$ & Orf,1999 \\
\hline 1 & Minsoy & Noir 1 & 240 & IM & RIL & Orf,1999 \\
\hline
\end{tabular}




\begin{tabular}{|c|c|c|c|c|c|c|}
\hline $\mathbf{1}$ & M82-806 & HHP & 71 & ANOVA & $\mathrm{F}_{2: 5}$ & Brummer,1997 \\
\hline $\mathbf{1}$ & M84-49 & Sturdy & 92 & ANOVA & $\mathrm{F}_{2: 5}$ & Brummer,1997 \\
\hline $\mathbf{3}$ & A87-29601 & CX1039-99 & 100 & ANOVA & $\mathrm{F}_{2: 5}$ & Brummer,1997 \\
\hline $\mathbf{3}$ & C1763 & CX1159-49 & 89 & ANOVA & $\mathrm{F}_{2: 5}$ & Brummer,1997 \\
\hline $\mathbf{3}$ & C1763 & CX1039-99 & 83 & ANOVA & $\mathrm{F}_{2: 5}$ & Brummer,1997 \\
\hline $\mathbf{1}$ & M81-382 & PI 423.949 & 81 & ANOVA & $\mathrm{F}_{2: 5}$ & Brummer,1997 \\
\hline $\mathbf{5}$ & PI97100 & Coker237 & 111 & ANOVA & $\mathrm{F}_{2}$ & Lee,1996 \\
\hline $\mathbf{6}$ & Young & PI416937 & 120 & ANOVA & $\mathrm{F}_{4}$ & Lee,1996 \\
\hline $\mathbf{5}$ & Minsoy & Noir 1 & 284 & ANOVA & RIL & Mansur,1996 \\
\hline $\mathbf{2}$ & Minsoy & Noir 1 & 284 & IM & RIL & Mansur,1993 \\
\hline $\mathbf{9}$ & A81-356022 & PI 468916 & 60 & ANOVA & $\mathrm{F}_{2: 3}$ & Diers,1992 \\
\hline $\mathbf{5}$ & $\begin{array}{c}\text { Misuzudaiz } \\
\text { u }\end{array}$ & $\begin{array}{c}\text { Moshidou } \\
\text { Gong 503 }\end{array}$ & - & ANOVA & - & Tajuddin,2003 \\
\hline Total:130 & \multicolumn{7}{|l}{} & & & \\
\hline
\end{tabular}

Table 1. Information of oil content QTLs

collected from Soybase and 28 published articles (Table 1). Mansur (1996) mapped five oil QTLs of soybean by the population Minsoy and Noir 1 with the ANOVA method. Sebolt (2000) mapped a oil QTLs of soybean by the population A81-356022 and PI 468916 with the Interval Mapping (IM) method. Hyten (2004) mapped six oil QTLs of soybean by the population Essex and Williams with the Composite Interval Mapping (CIM) method. Shan (2008) first reported the interaction between QTLs and environments with RIL population, crossed by Charleston and Dongnong594, with CIM and Multiple Interval Mapping(MIM) method.

The population used for above research involved RIL, $F_{2}, F_{4}, F_{2: 3}, F_{2: 5}$, and $B_{3} F_{4}$. Information on interval mapping (IM), composite interval mapping (CIM), multiple interval mapping (MIM), and the ANOVA analysis method was obtained. 1 to 11 QTLs were mapped from different papers.

\subsubsection{Protein concentration QTLs}

In the former researches, QTLs come from the 18 papers and soybase website listed in Table 2. Diers (1992) mapped eight protein QTLs of soybean by the population A81-356022 and PI 468916 with the ANVOA method. Furthermore, Diers (2000) reanalyzed and mapped a protein QTLs of soybean by the population A81-356022 and PI 468916 with the IM method, so the new QTLs were used in this study. In several cases, the same populations had been used by different research in independent experiments. For the Minsoy $\times$ Noir 1 population, Mansur (1996) mapped three protein QTLs of soybean with the ANVOA method, Orf (1999) mapped two protein QTLs of soybean with the IM method, Specht (2001) mapped five protein QTLs of soybean with the ANVOA method. For the Charleston $\times$ Dongnong 594 population, QTL $\times$ Environment effects were developed (Shan Dapeng et al., 2009), and used to reanalyze the new phenotypic data (Chen Qingshan et al., 2007; Zhang Zhongchen et al., 2004).

The set of 107 seed protein concentration QTL (Table 2) was obtained from 21 populations, varying in size from 60 to 284 . The analytical methods used to predict the QTL included ANOVA and both simple and composite interval mapping. The population type included RILs, $F_{2}, F_{2: 3}, F_{4}, F_{2: 5}$, and $B_{3} F_{4}$. A few QTLs with a LOD score below 2.0 were discarded from the analysis to reduce the risk of including false positives. 


\begin{tabular}{|c|c|c|c|c|c|c|}
\hline \begin{tabular}{|c|} 
QTL \\
Number
\end{tabular} & Parent1 & Parent2 & $\begin{array}{c}\text { Populatio } \\
\text { n Size }\end{array}$ & $\begin{array}{l}\text { Analysis } \\
\text { Method }\end{array}$ & $\begin{array}{c}\text { Populatio } \\
\text { n Type }\end{array}$ & Reference \\
\hline 10 & Charleston & Dongnong 594 & 154 & CIM & RIL & Shan,2009 \\
\hline 5 & Charleston & Dongnong 594 & 154 & CIM & RIL & Chen,2007 \\
\hline 2 & Charleston & Dongnong 594 & 154 & CIM & RIL & Zhang,2004 \\
\hline 3 & $\begin{array}{l}\text { Zheng } \\
92116\end{array}$ & Shang 951099 & 105 & IM & $\mathrm{F}_{2: 3}$ & Yang,2004 \\
\hline 3 & Kefeng 1 & $\begin{array}{c}\text { Nannong } \\
1138-2\end{array}$ & 201 & IM & RIL & Wu,2001 \\
\hline 1 & A3733 & PI437088A & 76 & ANOVA & RIL & Chung,2003 \\
\hline 1 & A81-356022 & PI468916 & 98 & IM & $\mathrm{BC}_{3} \mathrm{~F}_{4}$ & Sebolt,2000 \\
\hline 1 & Parker & PI468916 & 100 & IM & $\mathrm{BC}_{3} \mathrm{~F}_{4}$ & Sebolt,2000 \\
\hline 1 & M82-806 & $\mathrm{HHP}$ & 71 & ANOVA & $\mathrm{F}_{2: 5}$ & Brummer,1997 \\
\hline 1 & M84-49 & Sturdy & 92 & ANOVA & $\mathrm{F}_{2: 5}$ & Brummer,1997 \\
\hline 2 & McCall & PI 445.815 & 92 & ANOVA & $\mathrm{F}_{2: 5}$ & Brummer,1997 \\
\hline 2 & A87-29601 & CX1039-99 & 100 & ANOVA & $\mathrm{F}_{2: 5}$ & Brummer,1997 \\
\hline 3 & C1763 & CX1159-49 & 89 & ANOVA & $\mathrm{F}_{2: 5}$ & Brummer,1997 \\
\hline 2 & C1763 & CX1039-99 & 83 & ANOVA & $\mathrm{F}_{2: 5}$ & Brummer,1997 \\
\hline 1 & \begin{tabular}{|l|} 
LN83-2356 \\
\end{tabular} & PI 360.843 & 69 & ANOVA & $\mathrm{F}_{2: 5}$ & Brummer,1997 \\
\hline 2 & Archer & Minsoy & 233 & IM & RIL & Orf,1999 \\
\hline 1 & Archer & Noir 1 & 240 & IM & RIL & Orf,1999 \\
\hline 2 & Minsoy & Noir 1 & 240 & IM & RIL & Orf,1999 \\
\hline 10 & BSR 101 & LG82-8379 & 167 & ANOVA & RIL & Kabelka,2004 \\
\hline 6 & PI97100 & Coker237 & 111 & ANOVA & $\mathrm{F}_{2}$ & Lee,1996 \\
\hline 13 & Young & PI416937 & 120 & ANOVA & $\mathrm{F}_{4}$ & Lee,1996 \\
\hline 6 & Essex & Williams & 131 & CIM & RIL & Hyten,2004 \\
\hline 2 & Essex & Peking & 200 & ANOVA & $\mathrm{F}_{2: 3}$ & Qiu,1999 \\
\hline 4 & Ma.Belle & Proto & 82 & ANOVA & $\mathrm{F}_{2}$ & Csanadi,2001 \\
\hline 6 & $\begin{array}{c}\text { Misuzudaiz } \\
\mathrm{u} \\
\end{array}$ & $\begin{array}{l}\text { Moshidou } \\
\text { Gong } 503\end{array}$ & - & $\begin{array}{c}\text { ANOVA } \\
\text { IM }\end{array}$ & - & Tajuddin,2003 \\
\hline 1 & N87-984-16 & TN93-99 & 101 & ANOVA & RIL & Panthee,2005 \\
\hline 5 & Minsoy & Noir 1 & 236 & ANOVA & RIL & Specht,2001 \\
\hline 3 & Minsoy & Noir 1 & 284 & ANOVA & RIL & Mansur,1996 \\
\hline 8 & A81-356022 & PI 468916 & 60 & ANOVA & $\mathrm{F}_{2: 3}$ & Diers,1992 \\
\hline Total : & 107 & & & & & \\
\hline
\end{tabular}

Table 2. The origin of the set of seed protein concentration QTL included in the metaanalysis (The table details the number of QTL mapped in each population, along with the identity of the parents, the size and the type of each population)

\subsubsection{Fatty acid QTLs}

83 QTLs come from the 8 papers and soybase website were listed in Table 3. Among them, 16 QTLs were related with palmitic acid content; 11 QTLs related with stearic acid content; 32 QTLs related with oleic acid content; 10 QTLs related with linoleic acid content; and 14 
QTLs related with linolenic acid content. In 2007, Lee summerized 60 QTLs related with fatty acid from 2002 to 2008 . Some RFLP markers, not appear in the soybean public genetic map, were discarded. The analytical methods used to predict the QTL included ANOVA, IM, CIM, and MIM. The population type included RILs, $\mathrm{F}_{2}, \mathrm{~F}_{2: 3}, \mathrm{~F}_{4}$, RIL, and $\mathrm{BC}_{1} \mathrm{~F}_{1}$.

\begin{tabular}{|c|c|c|c|c|c|}
\hline Trait & Marker & LG & Population Type & Data analysis & Reference \\
\hline Palmitic acid & Satt537 & D1b & RIL & CIM & Panthee,2006 \\
\hline Palmitic acid & Satt330-Sat_155 & I & $\mathrm{BC}_{1} \mathrm{~F}_{1}$ & CIM MIM & Zheng, 2005 \\
\hline Palmitic acid & Satt175 & $\mathrm{M}$ & $\mathrm{F}_{2}$ & ANOVA & $\mathrm{Li}, 2002$ \\
\hline Palmitic acid & Sat_132 & $\mathrm{O}$ & RIL & CIM ANVOA & Yarmilla,2006 \\
\hline Palmitic acid & Satt684 & A1 & $\mathrm{F}_{4}$ & SAS & Andrea,2007 \\
\hline Stearic acid & Sat_245-Satt373 & $\mathrm{L}$ & $\mathrm{BC}_{1} \mathrm{~F}_{1}$ & CIM MIM & Zheng, 2005 \\
\hline Stearic acid & Satt249 & $\mathrm{J}$ & RIL & CIM & Panthee,2006 \\
\hline Stearic acid & Satt474 & $\mathrm{B} 2$ & $\mathrm{~F}_{2}$ & BSA & Spencer,2004 \\
\hline Stearic acid & Sat_090 & $\mathrm{F}$ & RIL & CIM \& ANVOA & Yarmilla,2006 \\
\hline Oleic acid & Satt143 & $\mathrm{L}$ & $\mathrm{F}_{2: 3}$ & CIM & Maria,2008 \\
\hline Oleic acid & Sat_356-Satt615 & D2 & $\mathrm{BC}_{1} \mathrm{~F}_{1}$ & CIM \& MIM & Zheng, 2005 \\
\hline Oleic acid & Satt263 & $E$ & RIL & CIM & Panthee,2006a \\
\hline Oleic acid & Satt163 & G & RIL & CIM ANVOA & Yarmilla,2006 \\
\hline Linoleic acid & Satt349 & K & RIL & CIM \& ANVOA & Yarmilla,2006 \\
\hline Linoleic acid & Satt166-Satt156 & $\mathrm{L}$ & $\mathrm{BC}_{1} \mathrm{~F}_{1}$ & CIM \& MIM & Zheng, 2005 \\
\hline Linoleic acid & Satt235 & G & RIL & CIM & Panthee,2006 \\
\hline Linoleic acid & Sat_274 & $\mathrm{O}$ & RIL & IM & Masayuki,2008 \\
\hline Linolenic acid & Satt579-Satt600 & D1b & $\mathrm{BC}_{1} \mathrm{~F}_{1}$ & CIM \& MIM & Zheng, 2005 \\
\hline Linolenic acid & Satt185 & $E$ & RIL & CIM & Panthee,2006 \\
\hline Linolenic acid & Satt349 & $\mathrm{K}$ & RIL & CIM \& ANVOA & Yarmilla,2007 \\
\hline
\end{tabular}

Table 3. Reported information of fatty acid QTLs in soybean

\subsubsection{Amino acid content QTLs}

For the QTL information of amino acid content, only 3 researches involved (Panthee, 2006b, 2006c; Bingchang Zhuang, 2000). In total, 111 QTLs were mapped with RIL population.

\subsubsection{Isoflavone content QTLs}

The reseach of isoflavone content was very few. 70 QTLs were mapped in 3 papers (Kassem, 2004; Meksem, 2001a; Guoliang Zeng, 2007) by RIL population.

\subsection{Collection of biotic stress resistance QTLs \\ 2.2.1 Fungal disease resistance QTLs}

Diseases caused by fungal pathogens account for approximately $50 \%$ of all soybean disease losses around the world. Conflicting results of fungal disease resistance QTLs from different populations often occurred. 107 QTLs in recent years of fungal disease resistance content were collected from 23 papers (Table 4). Only 1 to 5 QTLs were obtained in most researches. These QTLs had been mapped on the soybean linkage groups (LGs). not all fungal disease resistance content QTLs were collected because of some QTLs could not be projected to the reference map. 


\begin{tabular}{|c|c|c|c|}
\hline QTL number & Population-type & Name of fungal disease & Reference \\
\hline 5 & $\mathrm{~F}_{2}$ & Soybean rust & Alexandre, 2008 \\
\hline 2 & RIL & Brown stem rot & Bachman, 2001 \\
\hline 8 & RIL & Phytophthora root rot & Burnham, 2003 \\
\hline 3 & RIL & Phytophthora root rot & Weng, 2007 \\
\hline 2 & RIL & Asian soybean rust & Danielle, 2008 \\
\hline 5 & RIL & Sclerotinia stem rot, White mold & Guo, 2008 \\
\hline 1 & NIL & Soybean rust & Hyten, 2007 \\
\hline 5 & RIL & Sudden death syndrome & Kazi, 2008 \\
\hline 2 & RIL & Asian soybean rust & Monteros, 2007 \\
\hline 1 & $\mathrm{~F}_{2}$ & Frogeye leaf spot & Mian, 1999 \\
\hline 34 & RIL & Sclerotinia stem rot, White mold & Arahana, 2001 \\
\hline 1 & RIL & Frogeye leaf spot & Zhang, 2004 \\
\hline 3 & RIL & Sudden death syndrome & Njiti, 2002 \\
\hline 10 & RIL & Brown stem rot & Patzoldt, 2005a \\
\hline 6 & RIL & $\begin{array}{l}\text { Rhizoctonia root and Hypocotyl } \\
\text { rot }\end{array}$ & Zhao, 2005 \\
\hline 5 & $\mathrm{~F}_{2}$ & Sudden death syndrome & Austeclinio, 2007 \\
\hline 2 & RIL & Phytophthora root rot & Han, 2008 \\
\hline 2 & RIL & Brown stem rot & Lewers, 1999 \\
\hline 1 & NIL & Brown stem rot & Patzoldt, 2005b \\
\hline 4 & RIL & Sudden death syndrome & Iqbal, 2001 \\
\hline 2 & NIL & Sudden death syndrome & Meksem, 1999 \\
\hline 1 & RIL & Sudden death syndrome & Bell-Johnson, 1999 \\
\hline 2 & $\mathrm{~F}_{2}$ & Phomopsis seed decay & Berger, 1999 \\
\hline Total: 107 & & & \\
\hline
\end{tabular}

Table 4. QTLs information of fungal disease resistance in soybean

\subsubsection{Insect resistance QTLs}

81 QTLs from the 15 papers and soybase website were listed in Table 5. Among them, 12 QTLs were related with soybean aphid resistance, 42 QTLs related with corn ear worm(CEW) resistance, 11 QTLs related with common cut worm(CCW) resistance, and 16 QTL related with Mexican bean beetle and soybean pod borer resistance. The average interval of all above QTLs were $15 \mathrm{cM}$. The analytical methods used to predict the major site included BSA, ANOVA, IM, CIM, and MIM. The population type included RILs, $\mathrm{F}_{2}, \mathrm{~F}_{2: 3,}, \mathrm{~F}_{3: 4}$, $\mathrm{RIL}$, and $\mathrm{BC}_{6}$ population. 


\begin{tabular}{|l|c|c|l|l|}
\hline $\begin{array}{c}\text { Name of insect- } \\
\text { resistance }\end{array}$ & $\begin{array}{c}\text { QTL } \\
\text { number }\end{array}$ & $\begin{array}{c}\text { Population- } \\
\text { type }\end{array}$ & \multicolumn{1}{|c|}{$\begin{array}{c}\text { Analysis } \\
\text { Method }\end{array}$} & Reference \\
\hline Soybean aphid & 2 & $\mathrm{~F}_{2: 3}$ & BSA & Li,2007 \\
\hline Soybean aphid & 2 & $\mathrm{~F}_{2,} \mathrm{~F}_{2: 3}$ & BSA & Mian,2008 \\
\hline Soybean aphid & 8 & $\mathrm{~F}_{3: 4}$ & $\begin{array}{l}\text { CIM, MIM, } \\
\text { ANOVA }\end{array}$ & Zhang,2009 \\
\hline CCW & 2 & $\mathrm{~F}_{2}$ & CIM & Kunihiko,2005 \\
\hline CCW & 2 & RIL & CIM & Liu,2005 \\
\hline CCW & 3 & RIL & CIM & Fu,2007 \\
\hline CCW & 4 & $\mathrm{~F}_{2}$ & CIM & Kunihiko,2007 \\
\hline CEW & 2 & $\mathrm{~F}_{2: 3}$ & IM & Rector,2000 \\
\hline CEW & 2 & $\mathrm{~F}_{2}$ & ANOVA, IM & Rector,1998 \\
\hline CEW & 10 & $\mathrm{RIL}_{2}$ & SAS, IM & Terry, 1999 \\
\hline CEW & 20 & $\mathrm{RIL}_{2: 3}$ & IM & Terry, 2000 \\
\hline CEW & 5 & $\mathrm{~F}_{2: 3}$ & IM & Narvel, 2001 \\
\hline CEW, SBL & 3 & $\mathrm{BC}_{6} \mathrm{~F}_{2: 3}$ & ANOVA & Zhu, 2006 \\
\hline Mexican bean beetle & 1 & $\mathrm{~F}_{2: 3}$ & ANOVA & Boerma, 2005 \\
\hline Soybean pod borer & 15 & $\mathrm{RIL}$ & CIM & Zhao, 2008 \\
\hline Total & $\mathbf{8 1}$ & & & \\
\hline
\end{tabular}

Note: CIM, composite interval mapping; BSA, bulk segregant analysis; IM, Interval mapping; ANOVA, Analysis of variance; CCW, common cut worm; CEW, corn ear worm; SBL, Soybean looper

Table 5. QTLs information of insect-resistance in soybean

\subsubsection{Soybean cyst nematode resistance QTLs}

Soybean cyst nematode is a very serous disease, reducing yields by as much as 75 percent. Many research was focus on the major QTL mapping. 135 QTLs underlying SCN No.1, 2, 3, 4, 5, 6, and 14 resistance from 23 papers and soybase website were listed in Table 6. For different research, 1 to 19 QTLs were analyzed. The analytical methods included GLM, BSA, ANOVA, IM, and CIM. The population type included RILs, $F_{2}, F_{2: 3}, F_{4}$, RIL, NIL, and $\mathrm{BC}$.

\subsection{Collection of yield trait QTLs}

\subsubsection{0-Seed weight QTLs}

Soybean seed size is determined by the genetics of the variety and the environment where the seed was produced. In America, seed size was described as seeds per pound, but in China, seed size was often defined as 100-seed weight. So the research of QTL mapping for 100 -seed weight was mainly in China. Among them, the population crossed by Kefeng 1 and Nannong 1138-2 were used for 3 times. The analytical methods included IM and CIM. The population type included RILs and $F_{2}$. In total, 78 QTLs were collected(Table 5). 


\begin{tabular}{|c|c|c|c|}
\hline QTL number & Population-type & Analysis method & References \\
\hline 10 & $\mathrm{~F}_{2: 3}$ & CIM & Guo, 2006a \\
\hline 17 & $\mathrm{~F}_{2}$ & GLM & Kabelka, 2005 \\
\hline 4 & $\mathrm{~F}_{4}$ & CIM & Glover, 2004 \\
\hline 1 & RIL & GLM & Prabhu, 1999 \\
\hline 9 & $\mathrm{~F}_{2: 3}$ & CIM & Guo, 2006b \\
\hline 7 & $\mathrm{~F}_{2: 3}$ & GLM & Yue, 2001a \\
\hline 4 & $\mathrm{BC}_{3} \mathrm{~F}_{2: 3}, \mathrm{~F}_{2: 3}$ & IM & Schuster, 2001 \\
\hline 19 & $F_{2: 3}$ & GLM & Yue, 2001b \\
\hline 11 & $\mathrm{BC}_{1} \mathrm{~F}_{2}, \mathrm{BC}_{1} \mathrm{~F}_{4}$ & CIM,MIM & Lu weiguo, 2005 \\
\hline 1 & $\mathrm{~F}_{2}$ & BSA & Wang hui, 2007 \\
\hline 3 & RIL & BSA & Li Yongchun, 2007 \\
\hline 1 & RIL, NIL & ANOVA & Meksem, 2001b \\
\hline 4 & $\mathrm{~F}_{2}$ & BSA \& CIM & Meng Xi, 2008 \\
\hline 12 & $\mathrm{~F}_{2}, \mathrm{BC}_{1} \mathrm{~F}_{2}$ & CIM & Wang, 2001 \\
\hline 1 & $\mathrm{~F}_{2: 3}$ & Stepwise regression & Vierling, 1996 \\
\hline 3 & RIL & CIM & Ferdous, 2006 \\
\hline 6 & $\mathrm{~F}_{2: 3}$ & ANOVA & Qiu, 1999 \\
\hline 1 & NIL & ANOVA & Meksem, 1999 \\
\hline 9 & $\mathrm{~F}_{2: 3}$ & GLM & Brucker, 2005 \\
\hline 3 & $\mathrm{~F}_{2: 3}$ & GLM & Concibido, 1994 \\
\hline 1 & Population & GLM & Mahalingam, 1995 \\
\hline 5 & $\mathrm{~F}_{2: 3}$ & GLM & Heer, 1998 \\
\hline 3 & $\mathrm{~F}_{2: 3}, \mathrm{RIL}$ & ANOVA & Concibido, 1996 \\
\hline Total & 135 & & \\
\hline
\end{tabular}

Table 6. QTLs reported on resistance to soybean cyst nematode

\begin{tabular}{|c|c|c|c|c|c|}
\hline $\begin{array}{l}\text { No. of } \\
\text { QTLs }\end{array}$ & Parents & $\begin{array}{c}\text { Population } \\
\text { Size }\end{array}$ & $\begin{array}{l}\text { Analysis } \\
\text { methods }\end{array}$ & Population type & Reference \\
\hline 3 & Kefeng 1×Nannong 1138-2 & 201 & CIM & RIL & Gai,2007 \\
\hline 1 & Kefeng 1×Nannong 1138-2 & 184 & CIM & RIL & Zhang,2004 \\
\hline 6 & Kefeng $1 \times$ Nannong 1138-2 & 201 & IM & RIL & Wu,2001 \\
\hline 3 & $\begin{array}{ll}\text { Zheng } & 92116 \times \text { Shang } \\
951099 & \end{array}$ & 105 & IM & $\mathrm{F}_{2}$ & Guan,2004 \\
\hline 11 & $\begin{array}{l}\text { G.max } 7499^{\prime} \times \text { G.soja } \\
245331\end{array}$ & 148 & CIM & BIL & Li,2008 \\
\hline 8 & Charleston $\times$ Dongnong 594 & 154 & CIM & RIL & Chen,2007 \\
\hline 2 & $\begin{array}{l}\text { Jindou } \\
23 \times \text { Huibuzhiheidou }\end{array}$ & - & CIM & RIL & Wang,2004 \\
\hline 28 & $\begin{array}{l}\text { Zhongdou } 29 \times \text { Zhongdou } \\
32\end{array}$ & 255 & CIM & RIL & Wang,2008 \\
\hline 3 & Suinong $14 \times$ Suinong20 & 94 & CIM & $\mathrm{F}_{2}$ & Zhu, 2006 \\
\hline Total & 65 & & & & \\
\hline
\end{tabular}

Table 7. Information of 100-Seed Weight QTLs 


\subsubsection{Lodging QTLs}

Soybean (Glycine max [L.] Merr.) grain yields may be reduced when the plants lodge, So soybean lodging characteristics are an important consideration when conditions favor high yields. Lodging also creates harvesting problems. Where higher yields are obtained under irrigation, lodging is a major factor to consider in variety selection, water management, and planting density. 59 QTLs from 16 papers and soybase website were listed in Table 8. For different research, 1 to 8 QTLs were obtained. Most research only got only 1 to 2 QTLs. The analytical methods included IM, CIM, ANOVA, SSMD, and MNTECRLO. The population type included RILs and $\mathrm{F}_{2}, \mathrm{~F}_{5}$, and $\mathrm{BC}_{2} \mathrm{~F}_{4}$.

\begin{tabular}{|c|c|c|c|c|c|}
\hline $\begin{array}{l}\text { No. of } \\
\text { QTLs }\end{array}$ & Parents & $\begin{array}{c}\text { Population } \\
\text { size }\end{array}$ & $\begin{array}{l}\text { Analysis } \\
\text { Methods }\end{array}$ & $\begin{array}{c}\text { Population } \\
\text { type }\end{array}$ & Reference \\
\hline 4 & $\begin{array}{l}\text { Kefeng 1×Nannong } \\
1138-2\end{array}$ & 184 & CIM & RIL & Huang,2008 \\
\hline 6 & \begin{tabular}{|l} 
Zhongdou \\
$29 \times$ Zhongdou32
\end{tabular} & 165 & CIM & RIL & Zhou,2009 \\
\hline 6 & $\begin{array}{l}\text { Jindou } 23 \\
\times \text { Huibuzhiheidou }\end{array}$ & 257 & SSMD & RIL & Wang,2004 \\
\hline 7 & $\begin{array}{l}\text { Pis } \times \text { Beeson/ kenwood/ } \\
\text { Lawrence }\end{array}$ & 236 & CIM & RIL & Guzman,2007 \\
\hline 1 & G. $\max \times$ G. soja & 120 & CIM & RIL & $\mathrm{Li}, 2008$ \\
\hline 4 & Essex $\times$ Forrest & 100 & CIM & RIL & $\mathrm{Li}, 2008$ \\
\hline 1 & $\begin{array}{l}\text { Kefeng 1×Nannong 1138- } \\
2\end{array}$ & 206 & CIM & RIL & Zhang,2004 \\
\hline 1 & Essex $\times$ Forrest & 100 & CIM & RIL & Kassem,2006 \\
\hline 1 & $\begin{array}{l}\text { G. max IA2008xG. soja } \\
\text { PI468916 }\end{array}$ & 468 & CIM & $\mathrm{BC}_{2} \mathrm{~F}_{4}$ & Wang,2003 \\
\hline 8 & PI416937 × Young & 120 & ANOVA & $\mathrm{F}_{4}$ & Lee,1996 \\
\hline 5 & Minsoy $\times$ Noir 1 & 240 & IM & RIL & Orf,1999 \\
\hline 2 & Archer $\times$ Minsoy & 233 & $\mathrm{IM}$ & RIL & Orf,1999 \\
\hline 5 & Minsoy $\times$ Noir 1 & 236 & ANOVA & RIL & Chase,2001 \\
\hline 1 & --- & 177 & ANOVA & $\mathrm{F}_{4: 6}$ & Chase,2001 \\
\hline 2 & Noir $1 \times$ Minsoy & 284 & ANOVA & RIL & Mansur,1996 \\
\hline 1 & BSR $101 \times$ LG82-8379 & 167 & ANOVA & $\mathrm{F}_{5}$ & Kabelka, 2004 \\
\hline 1 & IA2008 × PI 468916 & 468 & MNTECRLO & $\mathrm{BC}_{2} \mathrm{~F}_{4}$ & Wang,2003 \\
\hline 2 & Coker237 × PI97100 & 111 & ANOVA & $\mathrm{F}_{2}$ & Lee,1996 \\
\hline 1 & --- & 248 & BSA & RIL & Mansur,1993 \\
\hline Total & 59 & & & & \\
\hline
\end{tabular}

Table 8. Information of lodging QTLs in soybean

\subsubsection{Plant height QTLs}

Plant height become one of important agronomic traits with the increase of planting density. Many factors affect the height of a soybean plant, but the genetic loci is the most important, and the rapid developments of molecular markers have provided powerful tools to map the height-related QTL at the genomic level. 93 QTLs from 13 papers and soybase website were 
listed in Table 9. For different research, 1 to 19 QTLs were obtained. The analytical methods were mainly IM and CIM. The population type included RILs and $F_{2}$.

\begin{tabular}{|c|c|c|c|c|c|}
\hline $\begin{array}{l}\text { No. Of } \\
\text { QTLs }\end{array}$ & Parents & $\begin{array}{c}\text { Population } \\
\text { size }\end{array}$ & $\begin{array}{l}\text { Analysis } \\
\text { methods }\end{array}$ & $\begin{array}{c}\text { Population } \\
\text { type }\end{array}$ & Reference \\
\hline 5 & Zheng92116×Shang951099 & 105 & IM & $\mathrm{F}_{2}$ & Guan,2004 \\
\hline 4 & Kefeng1×Nannong1138-2 & 201 & IM & RIL & $\mathrm{Wu}, 2001$ \\
\hline 19 & Zhongdou29×Zhongdou32 & 255 & CIM & RIL & Wang,2008 \\
\hline 5 & Suinong14×Suinong20 & 94 & CIM & $\mathrm{F}_{2}$ & Zhu,2006 \\
\hline 8 & Kefeng1×Nannong1138-2 & 184 & CIM & $\mathrm{F}_{2}$ & Zhang,2004 \\
\hline 1 & $\begin{array}{l}\text { G. } \max ^{\prime} 7499^{\prime} \times \text { G. soja PI } \\
245331\end{array}$ & 295 & CIM & RIL & Li,2008 \\
\hline 6 & G. $\max$ IA2008×PI 468916 & 468 & CIM & RIL & Wang,2004 \\
\hline 1 & Minsoy $\times$ Noir 1 & - & $\mathrm{IM}$ & RIL & Mansur,1993 \\
\hline 11 & BSR 101× LG82-8379 & 167 & - & RIL & Kabelka,2004 \\
\hline 2 & Essex $\times$ Williams & - & - & RIL & Chapman,2003 \\
\hline 8 & $\begin{array}{l}\text { Jindou } 23 \\
\times \text { Huibuzhiheidou }\end{array}$ & - & CIM & RIL & Wang Z,2004 \\
\hline 8 & Charleston $\times$ Dongnong594 & 154 & CIM & RIL & Chen,2007 \\
\hline 15 & Charleston×Dongnong594 & 147 & CIM \& MIM & RIL & Sun,2010 \\
\hline Total & 93 & & & & \\
\hline
\end{tabular}

Table 9. Information of soybean height QTLs

\subsection{Soybean growth stages QTLs}

Soybean growth stages divides plant development into vegetative $(\mathrm{V})$ and reproductive $(\mathrm{R})$ stages. The vegetative stages are numbered according to how many fully-developed trifoliate leaves are present. The reproductive $(R)$ stages begin at flowering and include pod development, seed development, and plant maturation. 98 QTLs from 10 papers and soybase website were listed in Table 10. For different research, 1 to 44 QTLs were obtained. The analytical methods were Multiple-QTL model, CIM, IECM, ANOVA, SIM, and Chisquare. The population type included $\mathrm{F}_{2}, \mathrm{RIL}$ and $\mathrm{BC}_{2}$.

\begin{tabular}{|c|c|l|l|}
\hline QTL-number & Population type & \multicolumn{1}{|c|}{ Analysis method } & \multicolumn{1}{|c|}{ References } \\
\hline 1 & $\mathrm{~F}_{2}$ & Multiple-QTL model & Naoki,2001 \\
\hline 13 & $\mathrm{~F}_{2}$ & CIM & Wang Zhen,2004 \\
\hline 3 & NIL & IECM & Wang Ying,2008 \\
\hline 14 & RIL & ANOVA & Green,2001 \\
\hline 10 & RIL & SIM & Adler,1999 \\
\hline 3 & RIL & ANOVA & Funastuki,2005 \\
\hline 5 & RIL & Chi-square & Chase,2001 \\
\hline 3 & BC $_{2}$ & CIM & Diers,2004 \\
\hline 2 & $\mathrm{~F}_{2}$ & ANOVA & Mansur,1996 \\
\hline 44 & RIL & CIM & Dawei Xin,2007 \\
\hline Total & 98 & & \\
\hline
\end{tabular}

Table 10. QTLs published of soybean growth stages 


\section{QTL projection and integration: a consensus map of soybean important agronomic traits}

\subsection{QTL projection of seed quality traits}

\subsubsection{Oil content $Q T L s$ projection on a consensus map}

In total, 110 QTLs for oil content were projected onto the reference map soymap2, and a consensus map was generated. The projected QTLs covered all LGs of the reference map (Fig. 1). Some QTLs could not be projected onto the reference map because they had no common markers with the reference map. As Fig. 1 shows, each LG contained many QTL clusters, and at least two original QTLs were found in each QTL cluster. On LG A1, 7 independent QTLs from different research were projected on the same interval.

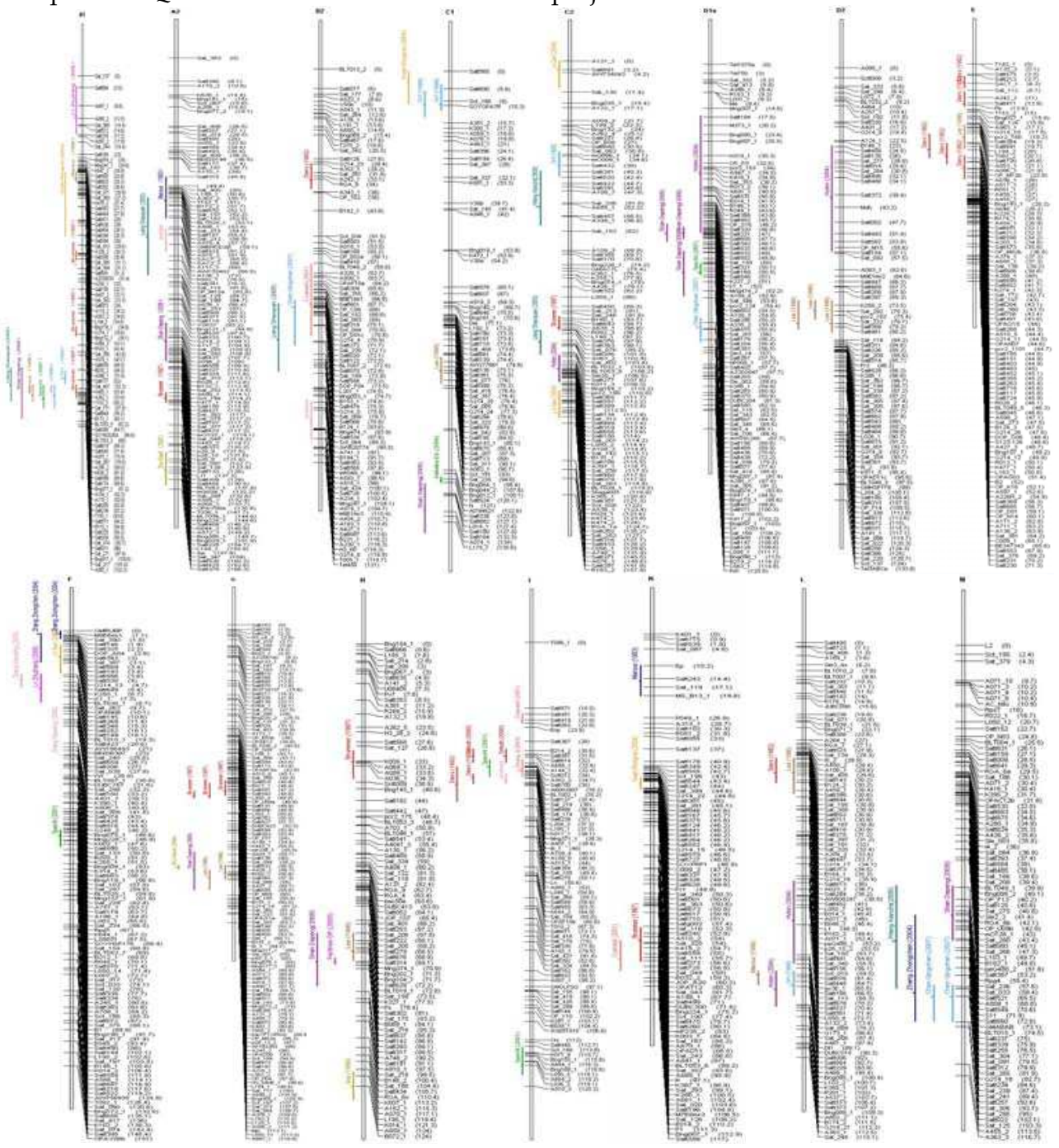

Fig. 1. Consensus map of soybean oil content 


\subsubsection{Protein concentration QTLs projection on a consensus map}

In total, 70 QTLs of 23 clusters identified, Fig. 2 illustrates the QTL clusters identified: there appear to be one very common site on chromosomes I, at this site, nine QTL was predicted from the various populations to be present. Four metaQTL sites, one each on chromosomes A1, B2, E, and M, at each of these sites, at least four QTL were predicted from the various populations to be present. Eighteen metaQTL site, one each on chromosomes A2, B1, B2, C1, C2, E, G, H, N and O. At each of these sites, at least two QTL were predicted from the various populations; the CIs of these clustered QTL shared a 3cM overlap with one another.

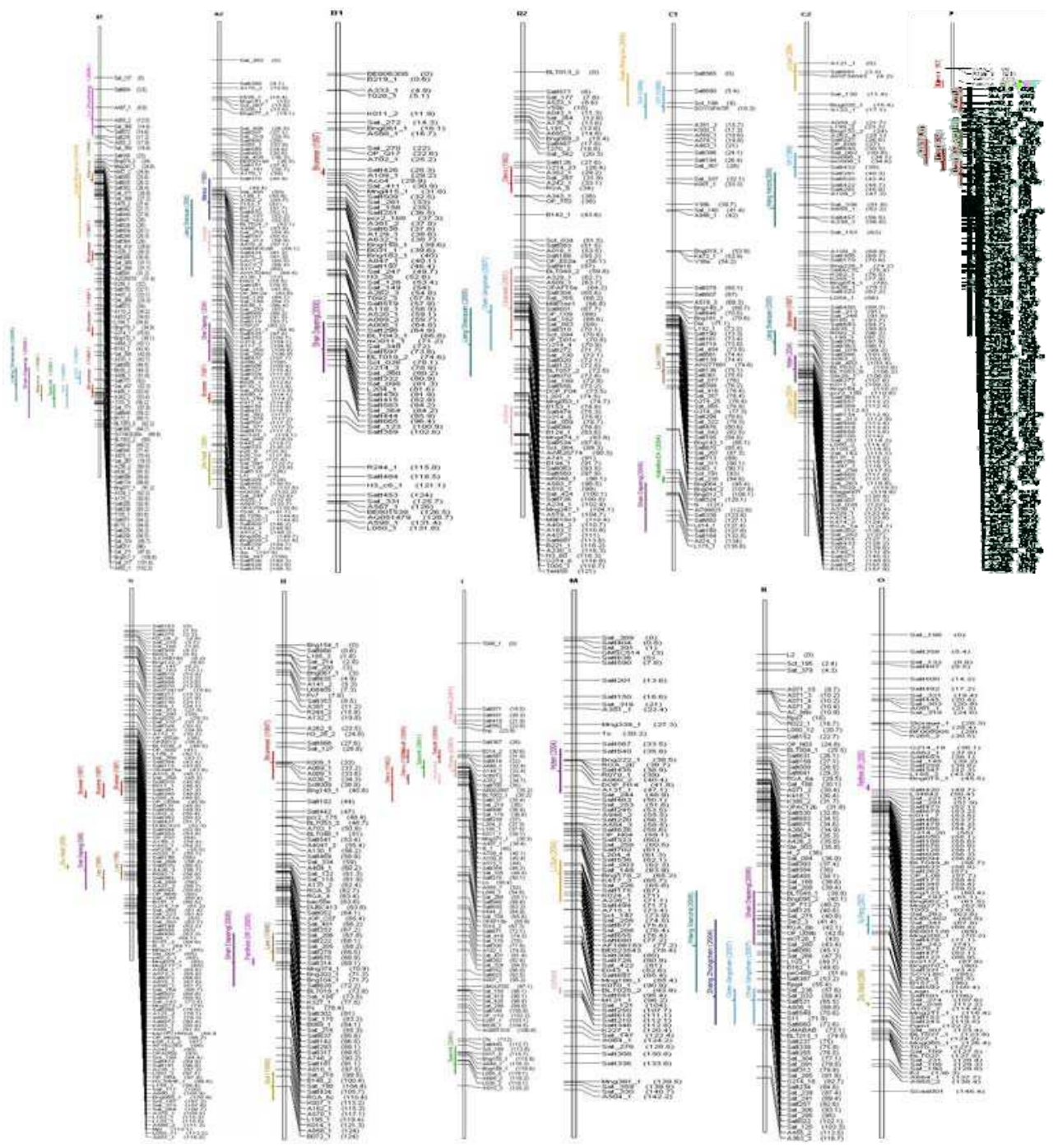

Fig. 2. Consensus map of soybean protein concentration 


\subsubsection{Fatty acid content QTLs projection on a consensus map}

Different genetic map with their QTLs were projected on the soybean public map Soymap2 to construct a consensus map of major QTLs for fatty acid content in soybean. The consensus QTLs distributed in clusters on A1, B2, D1b, D2, E, G, and L linkage groups (Fig.3).

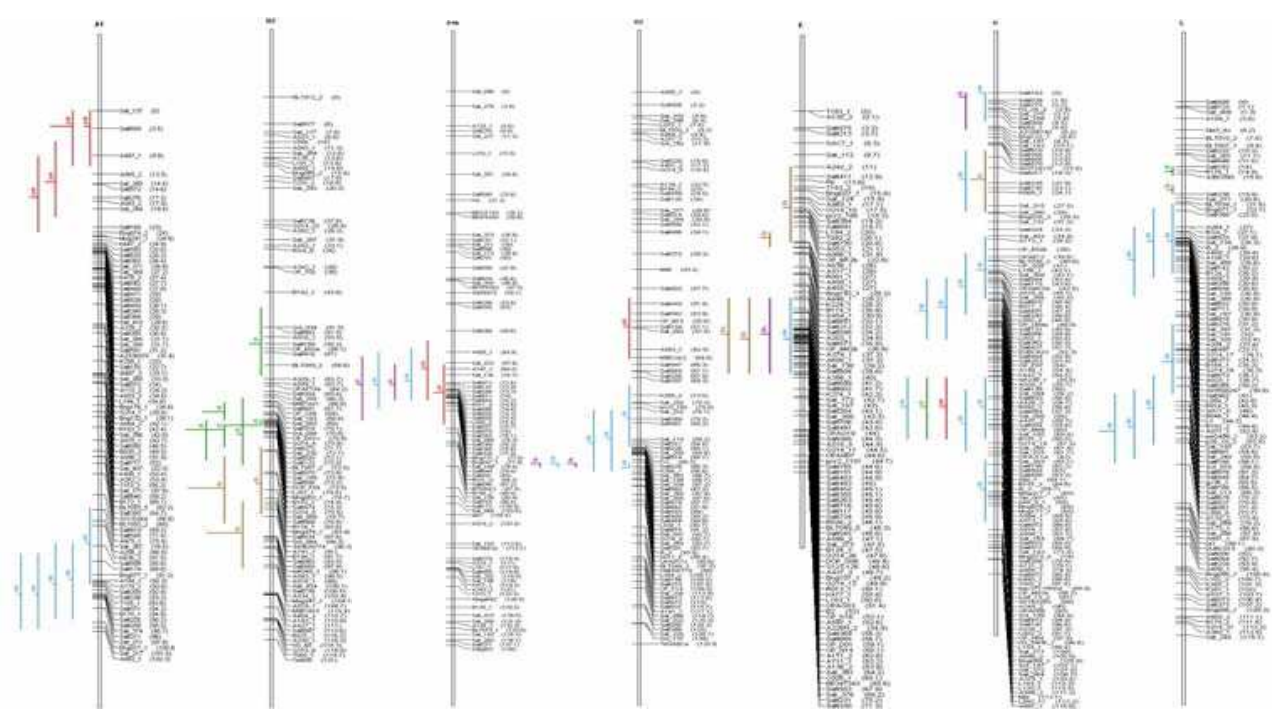

Fig. 3. Consensus map of fatty acid QTLs in soybean

\subsubsection{Amino acid content QTLs projection on a consensus map}

For amino acid content in soybean, 26 consensus QTLs for different amino acid on 16 linkage groups, that is A1, A2, B2, C1, D1a, D1b, D2, E, F, G, I, J, K, L, M, and O, were constructed (Fig.4). However, each consensus QTL included not only one kind but a few different kind of amino acids, which would be a key to explain that the same locus could influence the content of many kind of amino acids. 


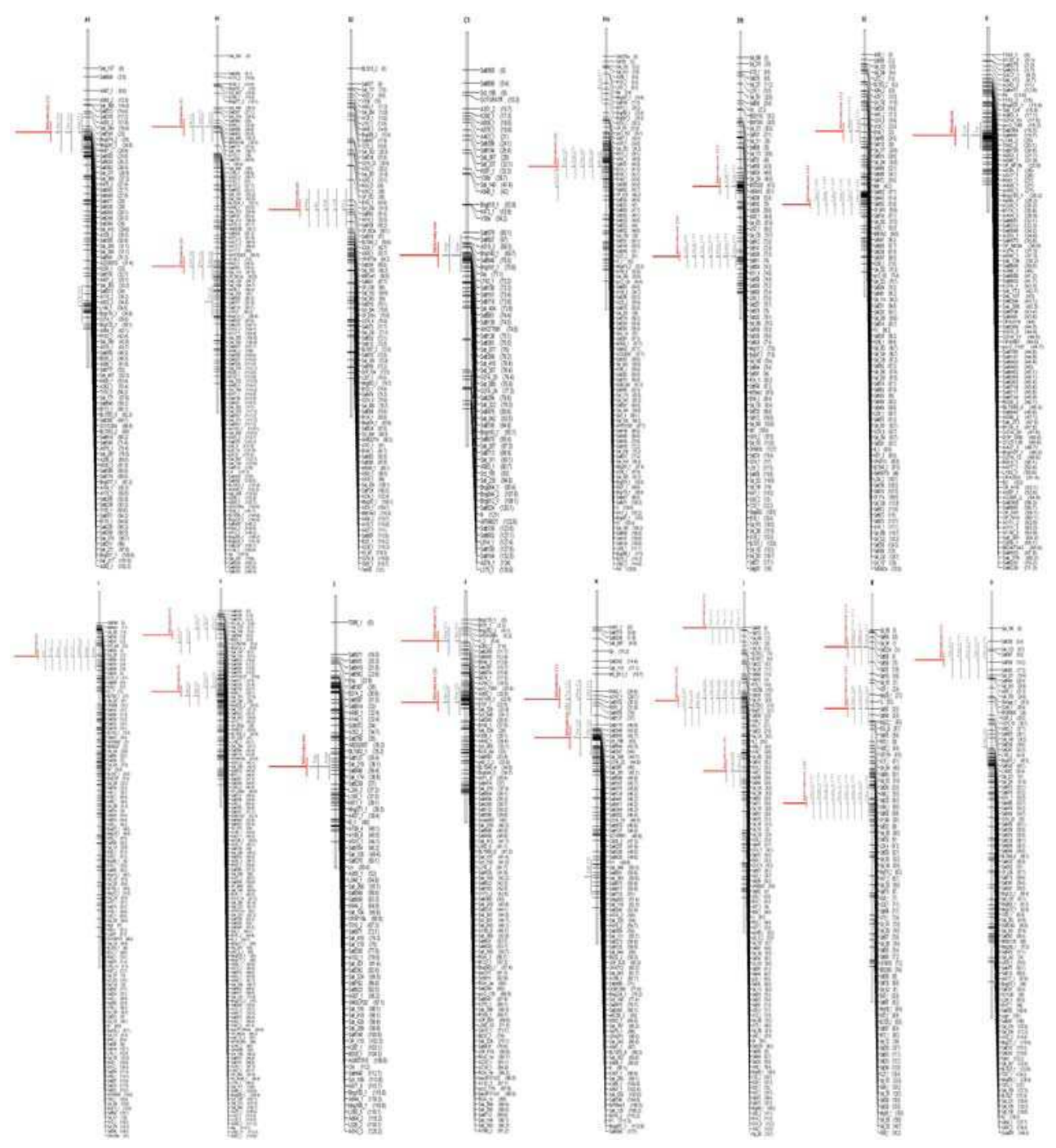

Fig. 4. Consensus map of Amino acid content QTLs in soybean

\subsubsection{Isoflavone content QTLs projection on a consensus map}

For isoflavone content in soybean, 10 consensus QTLs for different amino acid on 6 linkage groups, $\mathrm{A} 1, \mathrm{~B} 1, \mathrm{~B} 2, \mathrm{H}, \mathrm{K}$, and $\mathrm{N}$, were constructed. 


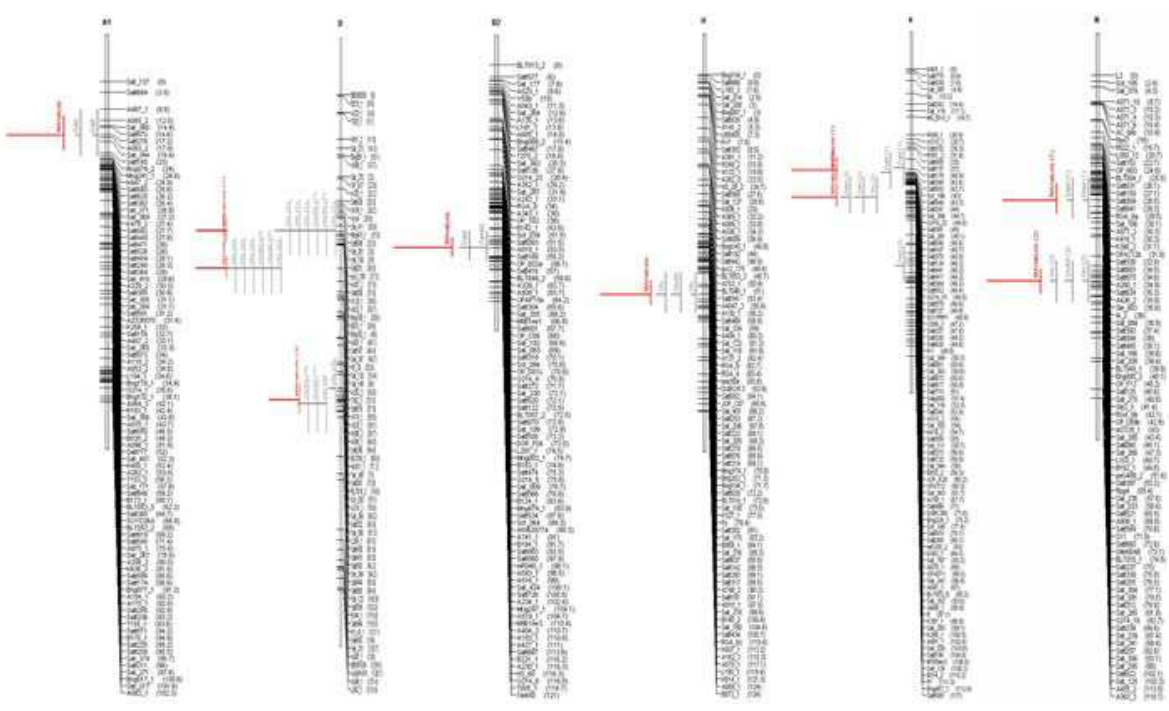

Fig. 5. Isoflavone content QTLs projection on a consensus map

\subsection{QTL projection of biotic stress resistance traits}

\subsubsection{Fungal disease resistance QTLs projection on a consensus map}

QTLs of original map were projected on the reference map by map-projection function of BioMercator2.1. In total, 107 QTLs of fungal disease resistance were projected on the reference map, soymap2, and a consensus map was obtained (Fig. 6).

As the Fig. 6 shown, projected QTLs were covered 11 linkage groups of the reference map. Although these original QTLs were mapped in different genetic backgrounds and with different methods, they were projected on the same regions by the common marker. If a QTL cluster contained more than two QTLs from different researches, this region could contain a potential allele in a high probability.

\subsubsection{Insect-resistance QTLs projection on a consensus map}

81 QTLs of original map were projected on the reference map. For single insect-resistance trait, the consensus QTLs mainly focused on 4 linkage groups, E, F, H, and M (Fig. 7 ). The cluster on linkage group $\mathrm{E}$ was obviously in a narrow interval. In detail, 3 consensus QTLs were distributed on linkage group $\mathrm{F}$ and $\mathrm{M}$ for soybean aphid-resistance. 9 consensus QTLs were discovered on 6 linkage group D1a, D2, E, G, H, and M for Corn Earworm. No consensus QTLs were found for Common Cutworm. For multiple insect-resistance trait, 14 concensus QTLs were combined on 8 linkage group D1a, D2, E, F, G, H, M, and N(Fig. not shown). 


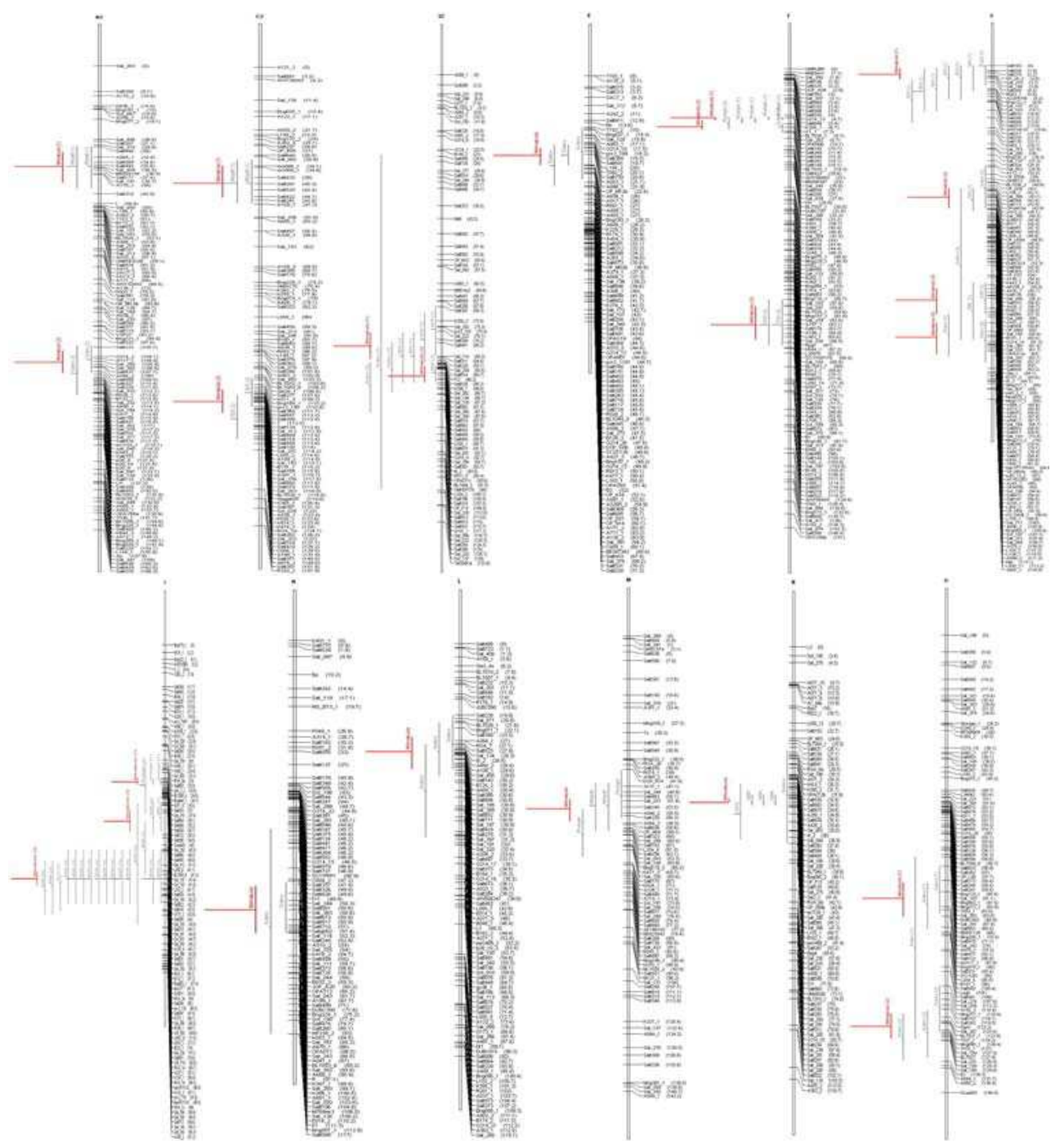

Fig. 6. QTLs of original map projection. BSR (Brown stem rot) ; Phytoph (Phytophthora root rot) ; ASR (Asian soybean rust) ; Sclero (Sclerotinia stem rot, White mold) ; SBR (Soybean rust) ; SDS (Sudden death syndrome) ; FLS (Frogeye leaf spot) ; RR-HR (Rhizoctonia root and Hypocotyl rot) ; PSD (Phomopsis seed decay) 


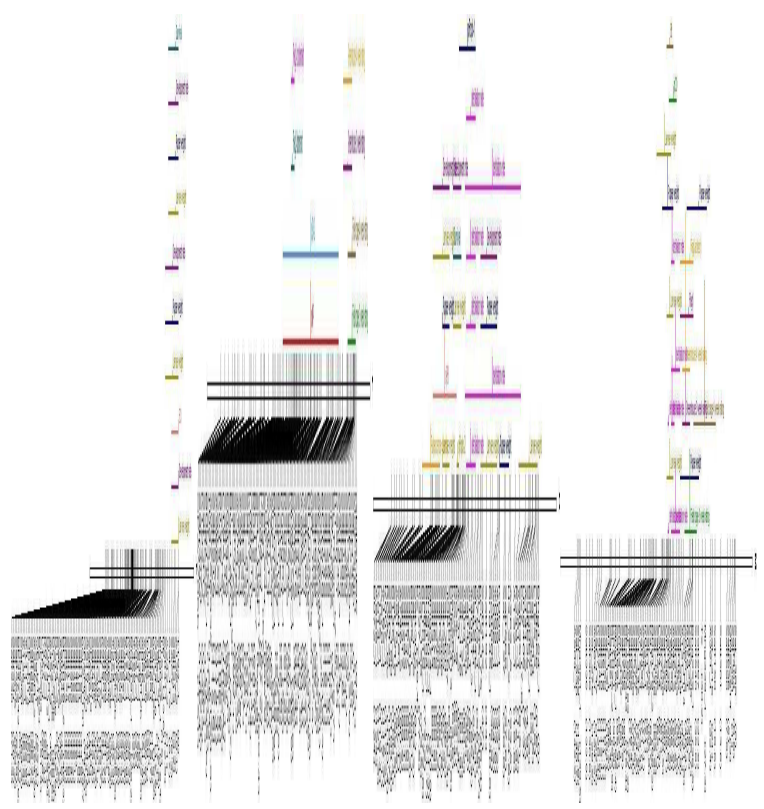

Fig. 7. Consensus map of insect-resistance QTLs in soybean

\subsubsection{Soybean cyst nematode resistance QTLs projection on a consensus map}

151 QTLs of original map were projected on the reference map(Fig. 8 ). 16 consensus QTLs on 8 linkage groups A2, B1, B2, D2, E, G, H, and J were integrated. In detail, 3 consensus QTLs were distributed on linkage group B1, B2, and G for SCN Race 1-resistance. 1 consensus QTLs were distributed on linkage group B1 for SCN Race 2-resistance. 7 consensus QTLs were distributed on linkage group A2, E, G, and J for SCN Race 3resistance. 3 consensus QTLs were distributed on linkage group A2, G, and H for SCN Race 4-resistance. 1 consensus QTLs were distributed on linkage group B1 for SCN Race 5resistance. 1 consensus QTLs were distributed on linkage group D2 for SCN Race 14resistance.

\subsection{QTL projection of yield traits}

\subsubsection{0 seed weight QTLs projection on a consensus map}

65 QTLs of original map were projected on the reference map (Fig. 9 ). 10 consensus QTLs on 9 linkage groups B1, C2, D2, K, M, and O were integrated for additive effect. 4 consensus QTLs on 3 linkage groups B2, H, and I were clusted for reductive effect.

\subsubsection{Lodging QTLs projection on a consensus map}

59 QTLs of original map were projected on the reference map(Fig. 10 ). 11 consensus QTLs were distributed on 5 linkage group, B1, C2, F, G, and L. Only one consensus cluster were found on linkage group B1 and G, but 2 on linkage group $\mathrm{C} 2$ and F, and 5 on linkage group L. 


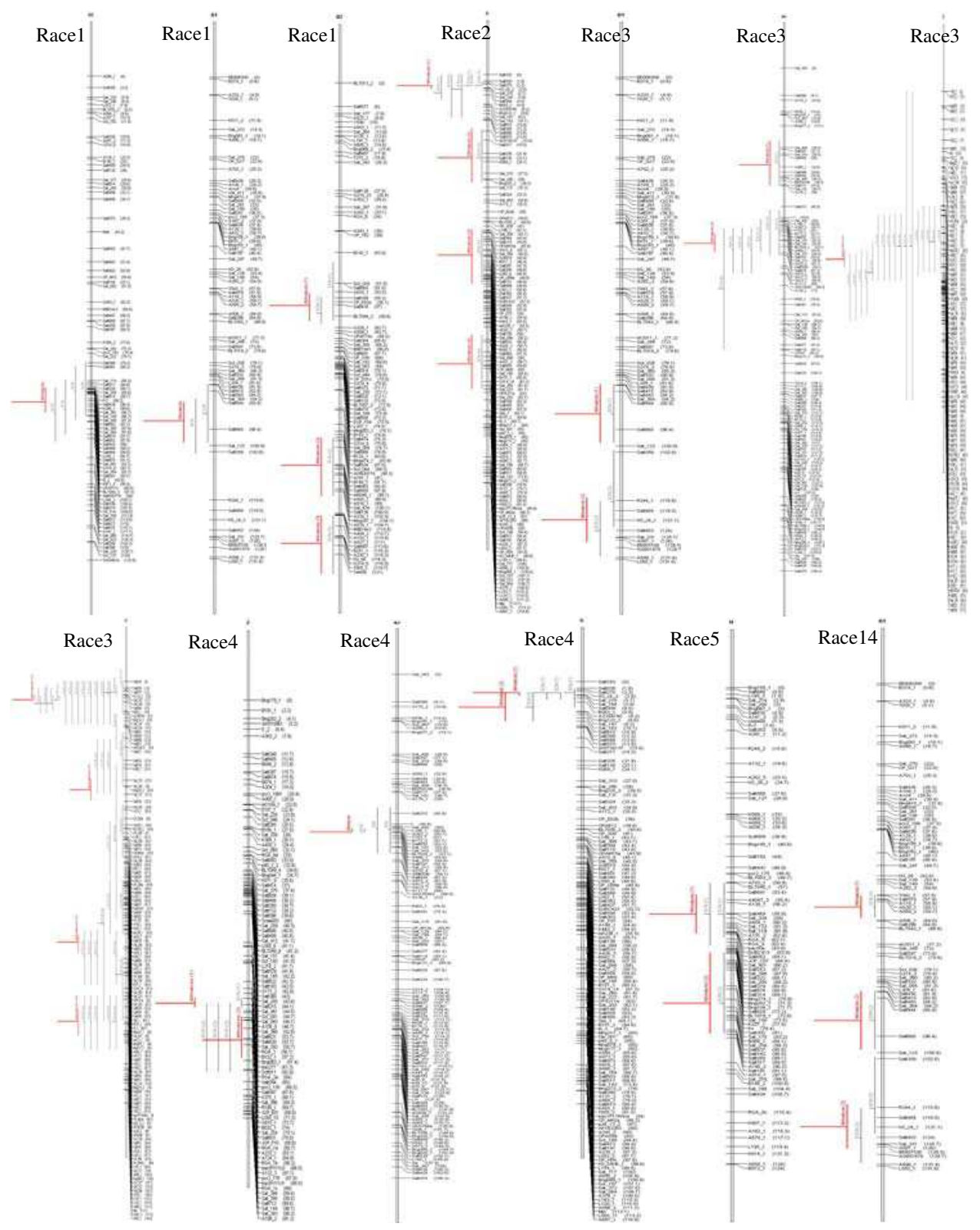

Fig. 8. Consensus map of QTLs resistant to SCN 


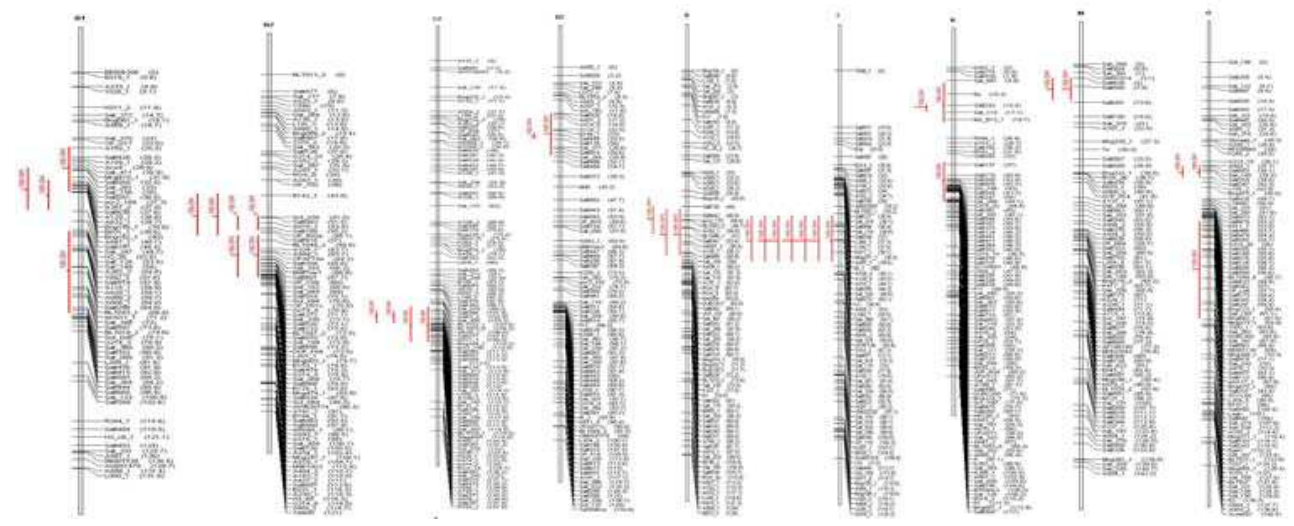

Fig. 9. Consensus map of 100 seed weight in soybean

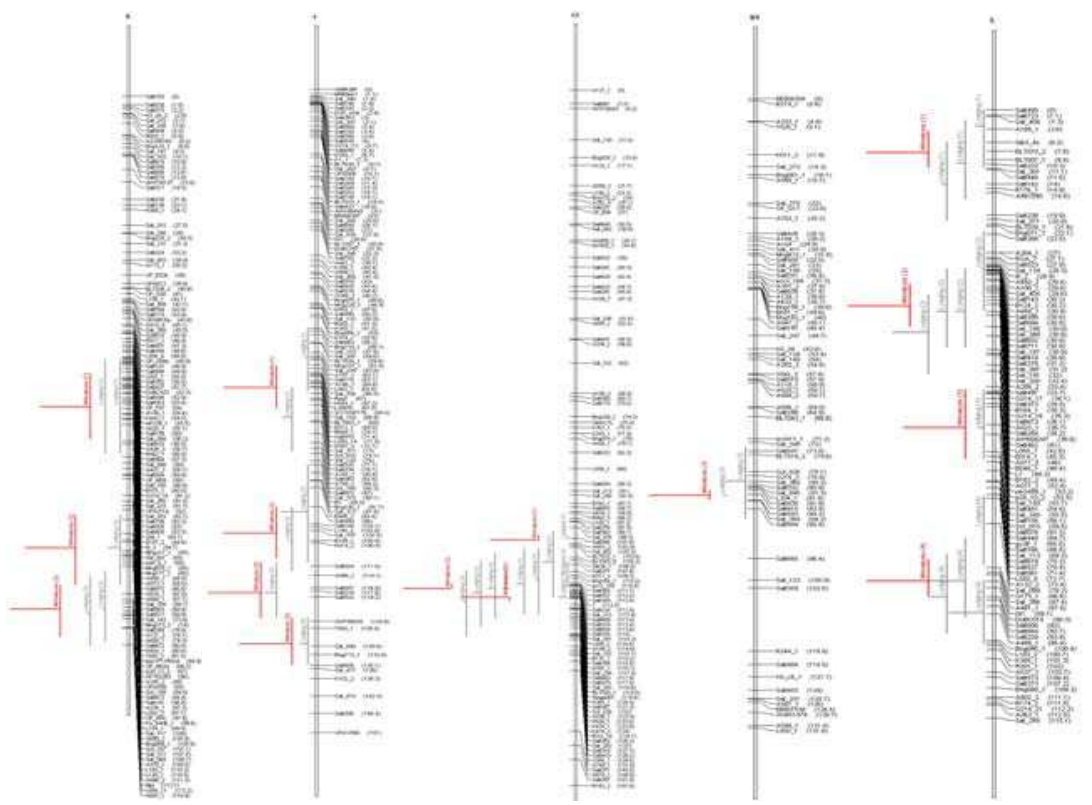

Fig. 10. Consensus map of Lodging QTLs

\subsubsection{Plant height QTLs projection on a consensus map}

78 QTLs of original map were projected on the reference map(Fig. 11 ). 12 consensus QTLs were distributed on 7 linkage group, B1, C2, D1a, F, G, K, and M. 

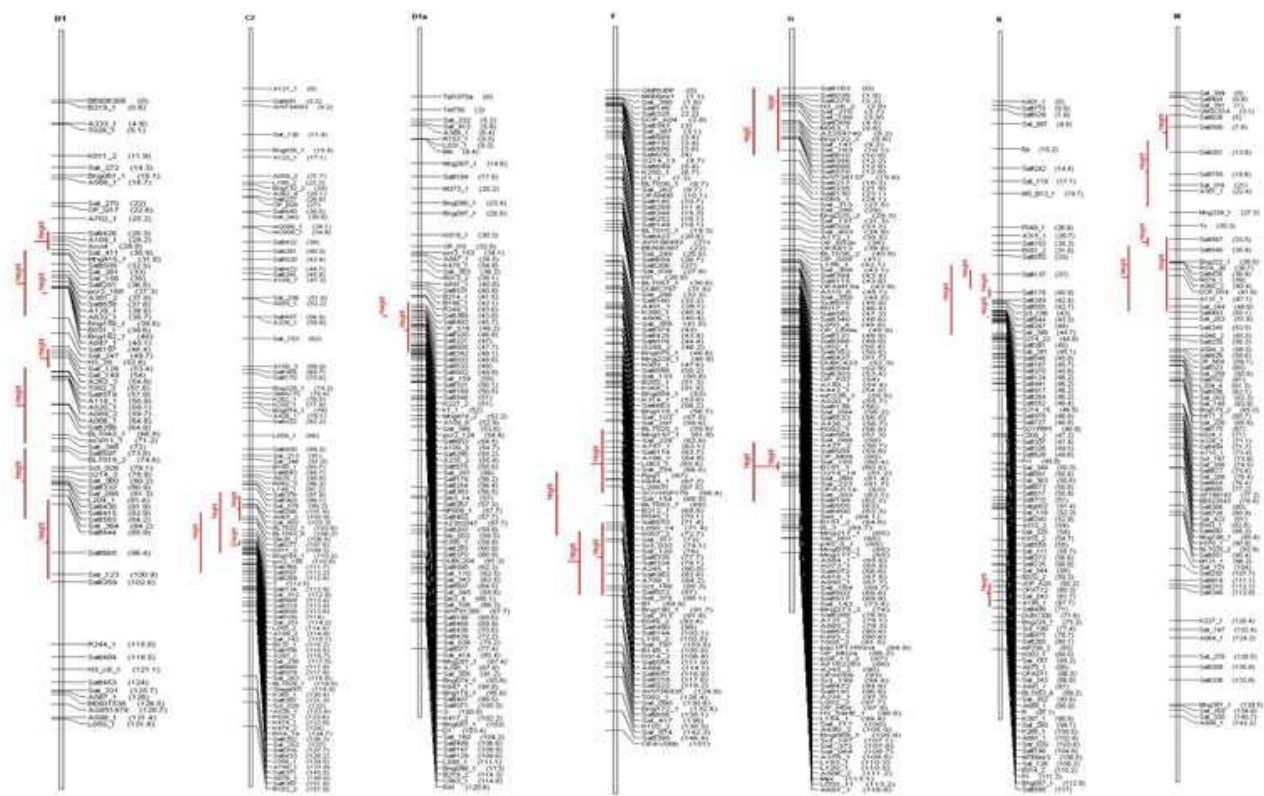

Fig. 11. Height QTLs projection on a consensus map

\subsection{Soybean growth stage QTLs projection on a consensus map}

98 QTLs of original map were projected on the reference map (Fig. 12). 7 consensus QTLs were distributed on 3 linkage group C2, L, and M for R1 period. 2 consensus QTLs were distributed on 2 linkage group C2 and L for R8 period. 10 consensus QTLs were distributed on 5 linkage group C1, D1a, D1b, F, and J for mixed periods(Fig. not all shown).

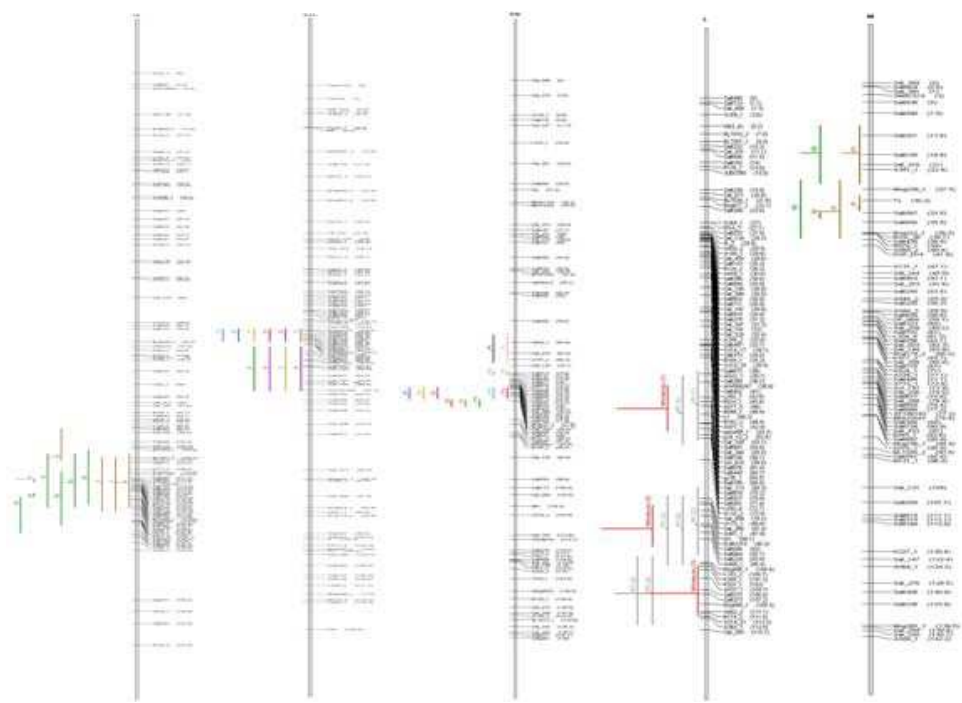

Fig. 12. Consensus map of soybean growth stage 


\section{Meta-analysis for important agronomic traits}

\subsection{Meta-analysis results of seed quality QTLs}

\subsubsection{Meta-analysis of Oil content QTLs}

A meta-analysis was carried out on the consensus QTL sites on 25 QTL clusters (Table 11 ). The site on linkage group A1 merged five QTL, with flanking markers at $92.56 \mathrm{cM}$ and $94.20 \mathrm{cM}$, a C.I. of $1.49 \mathrm{cM}$ and an $\mathrm{R}^{2}$ value of $10.83 \%$. The site on linkage group I merged five QTL into a single consensus QTL. The flanking markers for this site lay at $36.03 \mathrm{cM}$ and $49.30 \mathrm{cM}$, the CI of the QTL was $12.35 \mathrm{cM}$, and its $\mathrm{R}^{2}$ value was $18.22 \%$. The site on linkage group G merged four QTL into a single consensus QTL. The flanking markers for this site lay at $94.40 \mathrm{cM}$ and $96.60 \mathrm{cM}$, the CI of the QTL was $1.71 \mathrm{cM}$, and its $\mathrm{R}^{2}$ value was $13.27 \%$. The confidence interval at all sites ranged from $1.49-12.35 \mathrm{cM}$. The mean $\mathrm{R}^{2}$ values ranged from $5.5 \%$ to $39.15 \%$.

\begin{tabular}{|c|c|c|c|c|c|c|c|c|c|c|}
\hline LG & $\begin{array}{l}\text { AIC } \\
\text { value }\end{array}$ & \begin{tabular}{|c|} 
Meta- \\
QTL \\
position( \\
cM)
\end{tabular} & $\begin{array}{c}\text { 95\% C.I. } \\
\text { (cM) }\end{array}$ & $\begin{array}{l}\text { Map } \\
\text { distance }\end{array}$ & $\begin{array}{c}\text { Original } \\
\text { QTL } \\
\text { number }\end{array}$ & $\begin{array}{c}\text { Mean } \\
\mathrm{R}^{2}\end{array}$ & L-marker & $\begin{array}{c}\text { L-marker } \\
\text { Position } \\
(\mathrm{cM})\end{array}$ & R-marker & $\begin{array}{c}\mathrm{R}- \\
\text { marker } \\
\text { Position } \\
(\mathrm{cM})\end{array}$ \\
\hline A1 & 48.99 & 93.5 & 92.75-94.24 & 1.49 & 5 & \begin{tabular}{|l|}
10.83 \\
\end{tabular} & A170_1 & 92.56 & Satt511 & 94.20 \\
\hline A1 & 48.99 & 29.19 & $28.18-30.21$ & 2.03 & 2 & 29.18 & Satt454 & 28.08 & A329_2 & 30.28 \\
\hline A1 & 48.99 & 88.24 & $86.91-89.57$ & 2.66 & 2 & 38.41 & Satt599 & 85.58 & Bng077_1 & 91.24 \\
\hline A2 & 18.01 & 70.96 & $66.97-74.95$ & 7.98 & 2 & 39.15 & A111_1 & 67.328 & Satt341 & 77.695 \\
\hline B2 & 53.37 & 72.83 & $69.15-76.51$ & 7.36 & 3 & 9.56 & Sat_083 & 68.98 & Sat_009 & 78.66 \\
\hline $\mathrm{C} 1$ & 54.37 & 10.43 & 7.68-13.19 & 5.51 & 3 & 8.67 & Satt690 & 5.36 & A351_2 & 15.70 \\
\hline $\mathrm{C} 1$ & 54.37 & 123.94 & $\begin{array}{l}122.95- \\
124.93\end{array}$ & 1.98 & 2 & 13.6 & AI794821 & 122.63 & Satt338 & 123.79 \\
\hline $\mathrm{C} 2$ & 36.90 & 98.42 & $96.2-100.63$ & 4.43 & 2 & 5.50 & R092_3 & 96.13 & Sat_076 & 99.18 \\
\hline D1a & 28.99 & 57.45 & $56.53-58.36$ & 1.83 & 3 & 8.56 & Satt254 & 56.40 & Satt203 & 59.00 \\
\hline D1a & 28.99 & 70.74 & $68.87-72.62$ & 3.75 & 2 & 9.10 & Satt198 & 68.62 & Satt439 & 72.30 \\
\hline D2 & 22.25 & 77.41 & $75.24-79.58$ & 4.34 & 3 & 10.17 & Sat_292 & 75.29 & Satt461 & 80.20 \\
\hline $\mathrm{E}$ & 22.24 & 26.14 & 23.51-28.77 & 5.26 & 2 & 14.35 & OP_M12b & 22.84 & K229_1 & 28.30 \\
\hline E & 22.24 & 32.71 & 29.92-35.5 & 5.58 & 2 & 20.50 & K229_1 & 28.27 & Satt573 & 35.80 \\
\hline $\mathrm{F}$ & 27.42 & 2.16 & $1.29-3.02$ & 1.73 & 2 & 12.17 & M8E6mr1 & 1.09 & Satt343 & 3.04 \\
\hline $\mathrm{F}$ & 27.42 & 18.45 & $16.11-20.80$ & 4.69 & 2 & 13.59 & Satt252 & 16.08 & Satt423 & 20.56 \\
\hline G & 33.03 & 67.32 & $66.09-71.10$ & 5.01 & 3 & 12.53 & A073_1 & 68.56 & Sat_143 & 73.40 \\
\hline G & 33.03 & 95.12 & $94.26-95.97$ & 1.71 & 4 & 13.27 & Sct_199 & 94.40 & Satt191 & 96.60 \\
\hline $\mathrm{H}$ & 16.58 & 89.27 & $88.33-90.22$ & 1.89 & 3 & 9.63 & Satt142 & 86.49 & A748_2 & 90.30 \\
\hline I & 27.16 & 32.5 & $30.93-34.07$ & 3.14 & 2 & 27.00 & B214_2 & 30.56 & A352_2 & 34.70 \\
\hline $\mathrm{I}$ & 27.16 & 37.4 & $36.23-48.58$ & 12.35 & 5 & 18.22 & Sat_219 & 36.03 & Sat_105 & 49.30 \\
\hline K & 29.90 & 102 & $\begin{array}{l}98.26- \\
105.74 \\
\end{array}$ & 7.48 & 2 & 11.20 & $\mathrm{R}$ & 97.13 & M7E8mr3 & 107.00 \\
\hline $\mathrm{L}$ & 49.37 & 34.78 & $33.84-35.71$ & 1.87 & 2 & 19.50 & Satt497 & 33.71 & Satt613 & 36.10 \\
\hline $\mathrm{L}$ & 49.37 & 93.10 & $91.60-94.60$ & 3.00 & 3 & 11.83 & DUBC015 & 90.34 & A489_1 & 95.40 \\
\hline $\mathrm{N}$ & 17.54 & 73.14 & 69.19-77.09 & 7.90 & 2 & 6.57 & A808_1 & 68.76 & Sat_304 & 77.10 \\
\hline $\mathrm{N}$ & 15.19 & 95.56 & $92.22-98.90$ & 6.68 & 3 & 37.31 & Satt257 & 92.56 & Satt022 & 102.06 \\
\hline
\end{tabular}

Table 11. Meta-analysis results of oil content QTLs 


\subsubsection{Meta-analysis of protein concentration QTLs}

A meta-analysis was carried out on the consensus QTL sites on 23 QTL clusters (Table 12). The site on chromosome I merged nine QTL from seven populations, with flanking markers at $33.3 \mathrm{cM}$ and $37.0 \mathrm{cM}$, a CI of $3.7 \mathrm{cM}$ and an $\mathrm{R}^{2}$ value of $20.8 \%$. The site on chromosome A1 merged four QTL, predicted from four populations, into a single consensus QTL. The flanking markers for this site lay at $88.83 \mathrm{cM}$ and $97.49 \mathrm{cM}$, the CI of the QTL was $8.66 \mathrm{cM}$, and its R2 value was $9.4 \%$. The site on chromosome B2 merged four QTL, predicted from two populations, into a single consensus QTL. The flanking markers for this site lay at $71.7 \mathrm{cM}$ and $73.22 \mathrm{cM}$, the CI of the QTL was $1.52 \mathrm{cM}$, and its $\mathrm{R}^{2}$ value was $3.5 \%$. The site on chromosome $\mathrm{E}$ merged five QTL, predicted from three populations, into a single consensus QTL. The flanking markers for this site lay at $23.5 \mathrm{cM}$ and $30.3 \mathrm{cM}$, the CI of the QTL was $6.7 \mathrm{cM}$, and its $\mathrm{R}^{2}$ value was $7.4 \%$. The site on chromosome $\mathrm{M}$ merged five QTL (five populations), with flanking markers at $34.2 \mathrm{cM}$ and $41.5 \mathrm{cM}$, a CI of $7.2 \mathrm{cM}$ and an $\mathrm{R}^{2}$ value of $12.4 \%$. In total, twenty-three consensus QTL were detected. The confidence interval at all sites ranged from $1.52-14.31 \mathrm{cM}$, and the proportion of the phenotypic variance associated with each of them from $1.5 \%-20.8 \%$.

\begin{tabular}{|c|c|c|c|c|c|c|c|c|c|c|}
\hline LG & $\begin{array}{c}\text { AIC } \\
\text { value }\end{array}$ & $\begin{array}{l}\text { Meta-QTL } \\
\text { Position } \\
\text { (cM) }\end{array}$ & $\begin{array}{c}95 \% \text { C.I. } \\
\text { (cM) }\end{array}$ & $\begin{array}{c}\text { Map } \\
\text { distance }\end{array}$ & $\begin{array}{c}\text { Origina } \\
1 \\
\text { QTL } \\
\text { number }\end{array}$ & $\begin{array}{c}\text { Mean } \\
\mathrm{R}^{2}\end{array}$ & L-marker & $\begin{array}{c}\mathrm{L}- \\
\text { marker } \\
\text { Position } \\
(\mathrm{cM})\end{array}$ & R-m & $\begin{array}{c}\text { R-marker } \\
\text { Position } \\
\text { (cM) }\end{array}$ \\
\hline A1 & 15.64 & 93.16 & $88.83-97.49$ & 8.66 & 4 & 9.40 & Satt174 & 88.58 & Sat_271 & 97.76 \\
\hline A2 & 39.23 & 147.79 & $142.48-153.09$ & 10.61 & 2 & 3.10 & T036_1 & 141.08 & Satt228 & 154.11 \\
\hline B1 & 16.19 & 32.56 & $29.33-35.79$ & 6.46 & 3 & 7.00 & A109_1 & 29.17 & Satt251 & 36.48 \\
\hline B2 & 7.98 & 31.16 & $25.86-36.46$ & 10.60 & 2 & 14.50 & Sat_342 & 20.31 & A343_1 & 37.99 \\
\hline $\mathrm{B} 2$ & 7.98 & .65 & 44.35 & 10.60 & 2 & 6.80 & 1 & 43.58 & 168 & 55.20 \\
\hline B2 & 7.98 & 72.46 & $71.70-73.22$ & 1.52 & 4 & 3.50 & Satt272 & 71.68 & DOP_F04 & 73.54 \\
\hline $\mathrm{C} 1$ & 73.46 & 15.69 & 10.39-20.99 & 10.60 & 2 & 9.40 & SOYGPATR & 10.34 & A463_1 & 21.04 \\
\hline $\mathrm{C} 1$ & 73.46 & 63.08 & 57.78-68.38 & 10.60 & 2 & 13.70 & V38a & 54.19 & A519_3 & 69.30 \\
\hline C1 & 73.46 & 93.85 & $88.55-99.15$ & 10.60 & 2 & 11.00 & Sat_207 & 87.31 & Bng044_2 & 107.61 \\
\hline $\mathrm{C} 1$ & 73.46 & 123.76 & 119.43-128.09 & 8.66 & 3 & 13.20 & Bng012_1 & 108.08 & Satt164 & 132.46 \\
\hline $\mathrm{C} 2$ & 29.4 & 119.19 & \begin{tabular}{|c|}
$115.55-122.82$ \\
\end{tabular} & 7.27 & 3 & 15.40 & Satt708 & 115.49 & A538_1 & 123.37 \\
\hline \begin{tabular}{|l|}
$\mathrm{E}$ \\
\end{tabular} & 54.51 & 26.90 & $23.55-30.25$ & 6.70 & 5 & 7.40 & OP_M12b & 22.84 & B174_1 & 30.88 \\
\hline \begin{tabular}{|l|}
$\mathrm{E}$ \\
\end{tabular} & 54.51 & 45.21 & $43.88-45.98$ & 2.10 & 3 & 12.00 & Satt268 & 44.27 & R028_2 & 46.10 \\
\hline \begin{tabular}{|l|}
$\mathrm{E}$ \\
\end{tabular} & 18.24 & .40 & $56.08-66.72$ & 10.64 & 3 & 5.40 & A226H_2 & 54.85 & Satt553 & 67.92 \\
\hline \begin{tabular}{|l|}
$G$ \\
\end{tabular} & \begin{tabular}{|l|}
43.52 \\
\end{tabular} & 67.62 & $62.31-72.92$ & 10.61 & 2 & 13.80 & Satt199 & 62.16 & Sat_143 & 73.42 \\
\hline \begin{tabular}{|l|}
$G$ \\
\end{tabular} & \begin{tabular}{|l|}
43.52 \\
\end{tabular} & 93.60 & $88.30-98.91$ & 10.61 & 2 & 10.20 & AF162283 & 87.94 & L154_1 & 99.33 \\
\hline \begin{tabular}{|l|}
$\mathrm{H}$ \\
\end{tabular} & \begin{tabular}{|l|}
26.99 \\
\end{tabular} & 87.97 & $81.09-93.70$ & 12.61 & 3 & 9.20 & Satt302 & 81.04 & A810_1 & 97.53 \\
\hline \begin{tabular}{|l|l}
$\mathrm{I}$ \\
\end{tabular} & \begin{tabular}{|l|}
77.57 \\
\end{tabular} & 35.78 & $33.31-36.97$ & 3.66 & 9 & 20.80 & A144_1 & 32.42 & Satt239 & 36.94 \\
\hline $\mathrm{M}$ & 42.72 & 37.89 & $34.27-41.50$ & 7.23 & 5 & 12.38 & Satt567 & 33.47 & $\begin{array}{c}\text { DOP_H1 } \\
4\end{array}$ & 41.84 \\
\hline $\mathrm{N}$ & 18.33 & 32.38 & $27.07-37.68$ & 10.61 & 2 & 9.50 & Satt631 & 26.14 & Satt584 & 37.98 \\
\hline $\mathrm{N}$ & 9.78 & 79.50 & $74.50-84.50$ & 10.00 & 3 & 11.00 & BLT015_1 & 74.49 & Satt234 & 84.60 \\
\hline $\mathrm{N}$ & 9.78 & 98.03 & 94.02-102.06 & 8.04 & 2 & 1.50 & Sat_306 & 93.11 & Satt022 & 102.06 \\
\hline $\mathrm{O}$ & 14.12 & 72.10 & $64.95-79.26$ & 14.31 & 2 & 7.50 & Sat_282 & 63.81 & Satt477 & 82.09 \\
\hline
\end{tabular}

Table 12. Meta-analysis results of protein concentration QTL 


\subsubsection{Meta-analysis of Fatty acid QTLs}

A meta-analysis was carried out on the consensus QTL sites on 19 QTL clusters (Table 13 ). Some sites were related with only one trait. The site on linkage group A1, with flanking markers Sat_137 and A487_1, a C.I. of 7.44cM was related with Palmitic Acid Content. The site on linkage group B2, with flanking markers Sat_189 and Satt556, a C.I. of 0.4cM was related with Stearic Acid Content. The site on linkage group D2, with flanking markers Satt461 and Sat_114, a C.I. of 8.66 cM was related with Olelic Acid Content. The site on linkage group N, with flanking markers Satt530 and Satt683, a C.I. of 3.34cM was related with Linoleic Acid Content. The site on linkage group E, with flanking markers OP_M12b and A636_1, a C.I. of 3.09cM was related with Linolenic Acid Content. However, several sites were related with at least two traits. The site on linkage group C2, with flanking markers Sat_312 and Satt319, a C.I. of 10.6cM was related with Olelic Acid Content and Palmitic Acid Content. The site on linkage group D2, with flanking markers L026_1 and Satt615, a C.I. of 0.38cM was related with Linoleic Acid Content and Olelic Acid Content. The site on linkage group G, with flanking markers K493_1 and T005_2, a C.I. of 6.12cM was related with Olelic Acid Content, Pamitic Acid Content, and Stearic Acid Content.

\begin{tabular}{|c|c|c|c|c|c|c|c|}
\hline Trait & LG & AIC value & $\begin{array}{c}\text { Meta-QTL } \\
\text { position(cM) }\end{array}$ & $\begin{array}{c}95 \% \text { C.I. } \\
(\mathrm{cM})\end{array}$ & $\begin{array}{c}\text { Map } \\
\text { distance }\end{array}$ & L-marker & R-marker \\
\hline Pal & A1 & 64.01 & 3.54 & $0-7.44$ & 7.44 & Sat_137 & A487_1 \\
\hline Pal & A1 & 64.01 & 15.76 & $10.46-21.07$ & 10.61 & Satt572 & Satt276 \\
\hline Ole & A1 & 64.01 & 92.41 & $89.06-95.77$ & 6.71 & A104_1 & A170_1 \\
\hline St & B2 & 60.00 & 73 & $72.8-73.2$ & 0.4 & Sat_189 & Satt556 \\
\hline Lio & B2 & 60.00 & 90.49 & $86.19-94.78$ & 8.59 & AW620774 & A741_1 \\
\hline Ole,Pal & C2 & 11.04 & 113.39 & $108.09-$ & 118.69 & Sat_312 & Satt319 \\
\hline Pal & D1b & 28.81 & 73.12 & $70.57-75.67$ & 5.10 & Satt141 & Satt290 \\
\hline Ole & D2 & 34.21 & 83.00 & $78.67-87.33$ & 8.66 & Satt461 & Sat_114 \\
\hline Lin,Ole & D2 & 34.21 & 91.00 & $90.81-91.19$ & 0.38 & L026_1 & Satt615 \\
\hline Lio & E & 35.08 & 25.38 & $23.84-26.93$ & 3.09 & OP_M12b & A636_1 \\
\hline Lio,Ole & E & 35.08 & 45.09 & $41.34-48.84$ & 7.50 & Satt483 & Satt452 \\
\hline Ole,Lin & G & 127.82 & 0.72 & $0-3.65$ & 3.65 & Satt163 & Satt038 \\
\hline Ole,lin & G & 127.82 & 21.90 & $16.59-27.2$ & 10.61 & Satt235 & Satt130 \\
\hline Ole & G & 127.82 & 49.25 & $45.5-53$ & 7.50 & Satt131 & Satt566 \\
\hline Ole,Pal,St & G & 127.82 & 80.67 & $77.61-83.73$ & 6.12 & K493_1 & T005_2 \\
\hline Lin,Lio & K & 11.08 & 42.89 & $37.58-48.19$ & 10.61 & Satt555 & Sct_196 \\
\hline Ole & L & 69.71 & 31.89 & $27.56-36.22$ & 8.66 & Sat_397 & Sat_191 \\
\hline Ole & L & 69.71 & 66.11 & $62.36-69.86$ & 7.50 & gy3E_1 & Satt166 \\
\hline Lin & N & 6.69 & 34.09 & $32.42-35.76$ & 3.34 & Satt530 & Satt683 \\
\hline
\end{tabular}

Note: Pal, St, Ole, Lin, Lio were the abbreviation of Palmitic acid, Stearic acid, Oleic acid, Linoleic acid, and Linolenic acid, individually.

Table 13. Meta-analysis results of of fatty acid QTLs 


\subsubsection{Meta-analysis of amino acid content QTLs}

A meta-analysis was carried out on the consensus QTL sites on 26 QTL clusters (Table 14). Most sites were related with more than two kind of amino acid content. The site on linkage group A1, with flanking markers Sat_344 and Sat_410 at $19.38 \mathrm{cM}$ and $29.63 \mathrm{cM}$, a C.I. of $8.66 \mathrm{cM}$ was an admixture related with Glycine, Threonine, and Alanine content. The site with the minimal confidence interval on linkage group L, with flanking markers Satt495 and Sat_408 at $0.00 \mathrm{cM}$ and $1.31 \mathrm{cM}$, a C.I. of $1.86 \mathrm{cM}$ was related with Alanine, Glycine, Serine, Threonine, and Phenylalanine content. However, the site on linkage group M, with flanking markers GMSC514 and Satt201 at 3.05cM and $13.56 \mathrm{cM}$, a C.I. of $8.66 \mathrm{cM}$ was mainly related with Methionine content.

\begin{tabular}{|c|c|c|c|c|c|c|c|c|}
\hline LG & $\begin{array}{c}\text { AIC } \\
\text { value }\end{array}$ & $\begin{array}{c}\text { Meta-QTL } \\
\text { position }(\mathrm{cM})\end{array}$ & $\begin{array}{c}\text { 95\% C.I. } \\
\text { (cM) }\end{array}$ & \begin{tabular}{|c|} 
Map \\
distanc \\
$\mathrm{e}$
\end{tabular} & L-marker & $\begin{array}{l}\text { L-marker } \\
\text { Position } \\
\text { (cM) }\end{array}$ & R-marker & $\begin{array}{c}\text { R-marker } \\
\text { Position } \\
\text { (cM) }\end{array}$ \\
\hline A1 & 23.69 & 25.56 & $21.23-29.89$ & 8.66 & Sat_344 & 19.38 & Sat_410 & 29.63 \\
\hline $\mathrm{A} 2$ & 47.19 & 36.77 & $32.44-41.10$ & 8.66 & Satt589 & 33.96 & Satt315 & 45.29 \\
\hline $\mathrm{A} 2$ & 47.19 & 107.05 & $102.72-111.38$ & 8.66 & Satt233 & 100.09 & Sct_194 & 113.57 \\
\hline B2 & 24.61 & 55.2 & $51.45-58.95$ & 7.50 & Sct_034 & 51.45 & Satt416 & 56.96 \\
\hline $\mathrm{C} 1$ & 11.04 & 74.46 & 69.16-79.76 & 10.60 & Satt607 & 67.03 & Satt476 & 80.62 \\
\hline D1a & 47.19 & 59 & $55.65-62.35$ & 6.70 & Satt515 & 55.68 & Satt580 & 62.37 \\
\hline D1b & 53.30 & 75.67 & $70.37-80.97$ & 10.60 & Sat_135 & 70.65 & Satt644 & 79.42 \\
\hline $\mathrm{D} 1 \mathrm{~b}$ & 53.30 & 116.35 & $113.52-119.18$ & 5.66 & Sat_183 & 112.63 & Sat_198 & 118.95 \\
\hline D2 & 47.37 & 47.73 & $42.43-53.03$ & 10.6 & Satt372 & 39.35 & Satt582 & 53.85 \\
\hline D2 & 47.37 & 92.12 & $89.06-95.18$ & 6.12 & Satt488 & 89.20 & Satt301 & 93.71 \\
\hline $\mathrm{E}$ & 11.04 & 44.76 & $39.46-50.06$ & 10.60 & Sat_136 & 39.16 & Sat_273 & 47.50 \\
\hline $\mathrm{F}$ & 38.17 & 16.08 & $13.43-18.73$ & 5.30 & Satt269 & 11.37 & Satt149 & 18.13 \\
\hline G & 62.32 & 16.4 & $13.05-19.75$ & 6.7 & Satt570 & 12.74 & Satt235 & 21.89 \\
\hline G & 62.32 & 54.51 & $50.76-58.26$ & 7.50 & Satt303 & 53.42 & Sat_088 & 58.00 \\
\hline $\mathrm{I}$ & 11.04 & 82.78 & $77.48-88.08$ & 10.60 & Satt330 & 77.84 & Satt623 & 92.52 \\
\hline $\mathrm{J}$ & 23.69 & 11.74 & $6.44-17.04$ & 10.60 & AW310961 & 5.19 & Satt674 & 15.95 \\
\hline $\mathrm{J}$ & 23.69 & 43.01 & $37.71-48.31$ & 10.60 & Sat_370 & 37.40 & Sat_366 & 52.84 \\
\hline K & 40.45 & 30.28 & $25.95-34.61$ & 8.66 & Satt102 & 30.28 & Satt137 & 36.99 \\
\hline $\mathrm{K}$ & 40.45 & 46.63 & $41.33-51.93$ & 10.60 & Satt178 & 40.86 & Sat_116 & 52.28 \\
\hline $\mathrm{L}$ & 103.86 & 0.00 & $0.00-1.86$ & 1.86 & Satt495 & 0.00 & Sat_408 & 1.31 \\
\hline $\mathrm{L}$ & 103.86 & 31.72 & $29.22-34.22$ & 5.00 & Sat_405 & 29.62 & Satt313 & 34.54 \\
\hline $\mathrm{L}$ & 103.86 & 61.35 & $56.05-66.65$ & 10.6 & Satt156 & 56.14 & Satt166 & 66.51 \\
\hline $\mathrm{M}$ & 101.13 & 7.84 & $3.51-12.17$ & 8.66 & GMSC514 & 3.05 & Satt201 & 13.56 \\
\hline $\mathrm{M}$ & 101.13 & 33.47 & $29.14-37.80$ & 8.66 & Satt567 & 33.47 & Satt435 & 38.94 \\
\hline $\mathrm{M}$ & 101.13 & 73.37 & 70.87-75.87 & 5.00 & Satt494 & 71.71 & Sat_288 & 76.41 \\
\hline $\mathrm{O}$ & 35.53 & 13.60 & $10.25-16.95$ & 6.70 & Satt487 & 9.53 & Satt492 & 17.25 \\
\hline
\end{tabular}

Table 14. Meta-analysis results of amino acid content QTLs 


\subsubsection{Meta-analysis of isoflavone content QTLs}

A meta-analysis was carried out on the consensus QTL sites on 10 QTL clusters (Table 15 ). Although there were five sub-component of isoflavone content. Most sites were related with more than only one kind among them. The site on linkage group A1, with flanking markers Sat_368 and Satt165 at 10.60cM and $14.37 \mathrm{cM}$, a C.I. of $10.60 \mathrm{cM}$ was related with daidyzin content. The three sites on linkage group B1, with flanking left markers Sat_261, Satt 197, and Sct_026 at $32.95 \mathrm{cM}, 46.39$, and 78.13cM, corresponding right markers Satt638, Sat_247, and Satt 444 at $37.80 \mathrm{cM}, 49.73 \mathrm{cM}$, and $85.92 \mathrm{cM}$, the C.I. of $6.12 \mathrm{cM}, 6.12 \mathrm{cM}$, and $7.55 \mathrm{cM}$ were all related with Gly content.

\begin{tabular}{|c|c|c|c|c|c|c|c|c|}
\hline LG & $\begin{array}{c}\text { AIC } \\
\text { value }\end{array}$ & $\begin{array}{c}\text { Meta-QTL } \\
\text { position(cM) }\end{array}$ & $\begin{array}{c}\text { 95\% C.I. } \\
(\mathrm{cM})\end{array}$ & $\begin{array}{c}\text { Map } \\
\text { distanc } \\
\mathrm{e}\end{array}$ & L-marker & $\begin{array}{c}\text { L-marker } \\
\text { Position } \\
(\mathrm{cM})\end{array}$ & R-marker & $\begin{array}{c}\text { R-marker } \\
\text { Position } \\
(\mathrm{cM})\end{array}$ \\
\hline A1 & 11.04 & 17.16 & $11.86-22.46$ & 10.60 & Sat_368 & 14.37 & Satt165 & 23.00 \\
\hline B1 & 109.03 & 36.48 & $33.42-39.54$ & 6.12 & Sat_261 & 32.95 & Satt638 & 37.80 \\
\hline B1 & 109.03 & 46.39 & $43.33-49.45$ & 6.12 & Satt197 & 46.39 & Sat_247 & 49.73 \\
\hline B1 & 109.03 & 81.7 & $77.90-85.45$ & 7.55 & Sct_026 & 78.13 & Satt444 & 85.92 \\
\hline B2 & 11.04 & 93.49 & $88.19-98.79$ & 10.60 & Satt534 & 87.59 & Satt560 & 97.92 \\
\hline H & 15.57 & 81.04 & $76.71-85.37$ & 8.66 & Sat_158 & 73.46 & Satt637 & 85.79 \\
\hline K & 40.51 & 41.52 & $36.21-46.82$ & 10.61 & Satt055 & 32.96 & Satt727 & 46.80 \\
\hline K & 40.51 & 52.28 & $47.95-56.61$ & 8.66 & Satt337 & 47.38 & Satt273 & 56.62 \\
\hline N & 29.61 & 45.14 & $39.84-50.44$ & 10.60 & Sat_208 & 39.35 & Satt387 & 53.25 \\
\hline N & 29.61 & 74.99 & $70.66-79.32$ & 8.66 & Satt549 & 53.25 & Sat_091 & 79.51 \\
\hline
\end{tabular}

Table 15. Meta-analysis results of isoflavone content QTLs

\subsection{Meta-analysis results of biotic stress resistance QTLs \\ 4.2.1 Meta-analysis of fungal disease resistance QTLs}

A meta-analysis was carried out on the consensus QTL sites on 23 QTL clusters (Table 16 ). In total, 9 kind of soybean fungal disease-resistance QTLs were integrated. For brown stem rot, in short BSR, one site was the most notable cluster of integrating 14 former researches with flanking markers Sctt011 and Satt547 at $62.88 \mathrm{cM}$ and $67.79 \mathrm{cM}$ on linkage group J, a C.I. of 3.78cM. For phytophthora root rot, in short phytoph, one site was on linkage group $\mathrm{F}$ with flanking markers Satt252 and Satt149 at $16.08 \mathrm{cM}$ and $18.12 \mathrm{cM}$, a C.I. of $0.84 \mathrm{cM}$. Another was on linkage group J with flanking markers Satt414 and Satt596 at 37.04cM and $39.64 \mathrm{cM}$, a C.I. of $1.82 \mathrm{cM}$. For sclerotinia stem rot, in short Sclero, the former research results were more dispersed. one main site was on linkage group E with flanking markers Satt720 and A517_1 at 20.80cM and 26.02cM, a C.I. of 4.52cM. Another was on linkage group O with flanking markers Satt243 and Sat_190 at $119.50 \mathrm{cM}$ and $129.80 \mathrm{cM}$, a C.I. of $8.66 \mathrm{cM}$. For sudden death syndrome, in short SDS, one main site was on linkage group D2 with flanking markers Satt662 and Sat_001 at 87.88cM and 92.12cM, a C.I. of 4.11cM. Another was on linkage group $\mathrm{G}$ with flanking markers Satt163 and B053_1 at 0.00cM and 5.77cM, a C.I. of 4.21cM. Other results for remain diseases were listed in table and above Fig. 6. 


\begin{tabular}{|c|c|c|c|c|c|c|c|c|}
\hline LG & $\begin{array}{l}\text { AIC } \\
\text { value }\end{array}$ & $\begin{array}{c}\text { Meta-QTL } \\
\text { position }(\mathrm{cM})\end{array}$ & $\begin{array}{c}\text { 95\% C.I. } \\
\text { (cM) }\end{array}$ & $\begin{array}{c}\text { Map } \\
\text { distance }\end{array}$ & $\begin{array}{c}\text { L- } \\
\text { marker }\end{array}$ & $\begin{array}{c}\text { L-marker } \\
\text { Position } \\
\text { (cM) }\end{array}$ & R-marker & $\begin{array}{c}\text { R-marker } \\
\text { Position } \\
\text { (cM) }\end{array}$ \\
\hline $\mathrm{A} 2$ & 24.04 & 36.77 & 31.47-42.07 & 10.60 & Satt480 & 28.44 & Satt315 & 45.29 \\
\hline A2 & 24.04 & 106.72 & $\begin{array}{l}102.46- \\
110.98\end{array}$ & 8.52 & Satt233 & 100.09 & Satt329 & 110.94 \\
\hline $\mathrm{C} 2$ & 26.31 & 40.30 & $35.00-45.60$ & 10.60 & Sat_062 & 30.80 & Satt291 & 45.76 \\
\hline $\mathrm{C} 2$ & 26.31 & 115.47 & $\begin{array}{c}111.23- \\
119.70\end{array}$ & 8.47 & Satt365 & 111.68 & Staga001 & 119.85 \\
\hline D2 & 53.21 & 81.29 & 77.54-85.04 & 7.50 & Sat_222 & 76.69 & Satt226 & 85.15 \\
\hline D2 & 53.21 & 90.04 & 87.98-92.09 & 4.11 & Satt662 & 87.88 & Sat_001 & 92.12 \\
\hline$E$ & 13.94 & 23.85 & $21.59-26.11$ & 4.52 & Satt720 & 20.80 & A517_1 & 26.02 \\
\hline $\mathrm{F}$ & 32.21 & 16.91 & 16.49-17.33 & 0.84 & Satt252 & 16.08 & Satt149 & 18.12 \\
\hline $\mathrm{F}$ & 32.21 & 19.21 & 17.99-20.43 & 2.44 & Satt252 & 16.08 & Satt423 & 20.56 \\
\hline $\mathrm{F}$ & 32.21 & 84.17 & \begin{tabular}{|l|}
$78.87-89.47$ \\
\end{tabular} & 10.6 & Satt334 & 78.06 & Sat_313 & 91.87 \\
\hline G & 117.8 & 3.87 & $1.77-5.98$ & 4.21 & Satt163 & 0.00 & B053_1 & 5.77 \\
\hline$G$ & 117.8 & 46.80 & \begin{tabular}{|l|}
$43.31-50.29$ \\
\end{tabular} & 6.98 & Sat_308 & 43.09 & Satt352 & 50.53 \\
\hline$G$ & 117.8 & 83.00 & \begin{tabular}{|l|}
$78.20-87.79$ \\
\end{tabular} & 9.59 & A121_2 & 78.05 & AF162283 & 87.94 \\
\hline$G$ & 117.8 & 95.70 & 90.40-101.01 & 10.61 & A245_2 & 89.97 & Sat_117 & 100.00 \\
\hline $\mathrm{J}$ & 139.2 & 38.36 & $37.45-39.27$ & 1.82 & Satt414 & 37.04 & Satt596 & 39.64 \\
\hline $\mathrm{J}$ & 139.2 & 49.98 & $46.98-52.98$ & 6.00 & Sat_093 & 46.09 & Sat_366 & 52.84 \\
\hline $\mathrm{J}$ & 139.2 & 65.66 & 63.77-67.55 & 3.78 & Sctt011 & 62.88 & Satt547 & 67.79 \\
\hline $\mathrm{K}$ & 13.94 & 80.43 & 73.15-87.71 & 14.56 & Satt499 & 71.00 & A841_1 & 87.04 \\
\hline $\mathrm{L}$ & 19.65 & 30.93 & 26.02-35.85 & 9.83 & Satt388 & 23.55 & Satt613 & 36.05 \\
\hline $\mathrm{M}$ & 25.49 & 54.83 & 51.08-58.58 & 7.50 & \begin{tabular}{|l|} 
Satt463 \\
\end{tabular} & 50.10 & Satt626 & 58.60 \\
\hline $\mathrm{N}$ & 15.83 & 42.15 & $41.40-42.91$ & 1.51 & Sat_275 & 40.81 & Sat_280 & 43.45 \\
\hline $\mathrm{O}$ & 43.87 & 84.99 & \begin{tabular}{|l|}
$79.77-90.21$ \\
\end{tabular} & 10.44 & A878_1 & 78.33 & Bng070_1 & 89.98 \\
\hline $\mathrm{O}$ & 43.87 & 125.43 & $\begin{array}{l}121.10- \\
129.76\end{array}$ & 8.66 & Satt243 & 119.50 & Sat_190 & 129.80 \\
\hline
\end{tabular}

Table 16. Meta-analysis results of fungal disease resistance QTLs

\subsubsection{Meta-analysis of insect-resistance QTLs}

A meta-analysis was carried out on the consensus QTL sites on 14 QTL clusters (Table 17 ). The QTL intervals were reduced from $15 \mathrm{cM}$ to $3.67 \mathrm{cM}$ in average. For single insectresistance, only the sites of soybean aphid-resistance and corn earworm-resistance got the meta-analysis results. 3 true QTLs were related with soybean aphid resistance. Two sites were on linkage group F, with flanking left markers j11_1 and R045_1 at $7.31 \mathrm{cM}$ and $70.12 \mathrm{cM}$, corresponding right markers BLT030_1 and Satt510 at 8.67cM and 71.41cM, the C.I. of $4.68 \mathrm{cM}$ and $2.37 \mathrm{cM}$. The other was on linkage group $\mathrm{M}$ with flanking markers DOP_H14 and A131_1 at 41.84cM and 47.12cM, a C.I. of 4.07cM. 9 true QTLs were related with corn earworm resistance. One site was on linkage group D1a with flanking markers Sat_353 and R013_2 at 36.23cM and 38.09cM, a C.I. of 6.02cM. Another was on linkage group G with flanking markers Satt 472 and Satt191 at $94.84 \mathrm{cM}$ and $96.57 \mathrm{cM}$, a C.I. of 1.22cM. Others were shown in the Table 17. 
Most QTLs were related with mutiple insect-resistance(Table 18). For example, The site on linkage group E, with flanking markers A135_3 and Satt575 at 0.06cM and 3.30cM, a C.I. of $3.11 \mathrm{cM}$ was related with corn earworm resistance and common cutworm.

\begin{tabular}{|c|c|c|c|c|c|c|c|c|c|}
\hline Trait & LG & $\begin{array}{c}\text { AIC } \\
\text { value }\end{array}$ & $\begin{array}{c}\text { Meta-QTL } \\
\text { position(c } \\
\text { M) }\end{array}$ & $\begin{array}{c}\text { 95\% C.I. } \\
(\mathrm{cM})\end{array}$ & $\begin{array}{c}\text { Map } \\
\text { distance }\end{array}$ & L-marker & $\begin{array}{c}\text { L- } \\
\text { marker } \\
\text { Position } \\
(\mathrm{cM})\end{array}$ & R-marker & $\begin{array}{c}\text { R- } \\
\text { marker } \\
\text { Position } \\
(\mathrm{cM})\end{array}$ \\
\hline Soybean aphid & F & 30.07 & 7.56 & $5.22-9.90$ & 4.68 & j11_1 & 7.31 & BLT030_1 & 8.67 \\
\hline Soybean aphid & F & 30.07 & 71.09 & $69.90-72.27$ & 2.37 & R045_1 & 70.12 & Satt510 & 71.41 \\
\hline Soybean aphid & M & 34.20 & 43.85 & $41.82-45.89$ & 4.07 & DOP_H14 & 41.84 & A131_1 & 47.12 \\
\hline CEW & D1a & 15.8 & 38.08 & $35.07-41.09$ & 6.02 & Sat_353 & 36.23 & R013_2 & 38.09 \\
\hline CEW & D2 & 10.64 & 100.12 & $95.33-104.92$ & 9.59 & GMHSP179 & 99.04 & Satt186 & 105.45 \\
\hline CEW & E & 48.13 & 2.14 & $0.59-3.70$ & 3.11 & A135_3 & 0.06 & Satt575 & 3.30 \\
\hline CEW & G & 8.77 & 95.71 & $95.10-96.32$ & 1.22 & Satt472 & 94.84 & Satt191 & 96.57 \\
\hline CEW & H & 145.95 & 38.53 & $35.69-41.37$ & 5.68 & A036_1 & 34.29 & Sctt009 & 38.89 \\
\hline CEW & H & 145.95 & 57.34 & $54.52-60.16$ & 5.64 & A130_1 & 56.18 & Satt469 & 58.91 \\
\hline CEW & H & 145.95 & 77.32 & $75.9-78.74$ & 2.84 & Sat_158 & 73.46 & K327_1 & 77.53 \\
\hline CEW & M & 31.68 & 56.69 & $55.28-58.11$ & 2.83 & Satt220 & 56.29 & A584_3 & 58.50 \\
\hline CEW & M & 31.68 & 60.75 & $60.46-61.03$ & 0.57 & Sat_258 & 60.47 & Satt702 & 61.04 \\
\hline
\end{tabular}

Table 17. Meta-analysis results of single insect-resistance QTLs

\begin{tabular}{|c|c|c|c|c|c|c|c|c|}
\hline LG & $\begin{array}{c}\text { AIC } \\
\text { value }\end{array}$ & $\begin{array}{c}\text { Meta-QTL } \\
\text { position(cM) }\end{array}$ & $\begin{array}{c}\text { 95\% C.I. } \\
(\mathrm{cM})\end{array}$ & Map distance & L-marker & $\begin{array}{c}\text { L-marker } \\
\text { Position } \\
(\mathrm{cM})\end{array}$ & R-marker & $\begin{array}{c}\text { R-marker } \\
\text { Position } \\
(\mathrm{cM})\end{array}$ \\
\hline D1a & 25.01 & 38.08 & $35.07-41.09$ & 6.02 & Sat_353 & 36.23 & R013_2 & 38.09 \\
\hline D2 & 10.64 & 100.12 & $95.33-104.92$ & 9.59 & GMHSP179 & 99.04 & Satt186 & 105.45 \\
\hline E & 48.13 & 2.14 & $0.59-3.70$ & 3.11 & A135_3 & 0.06 & Satt575 & 3.30 \\
\hline F & 50.58 & 7.56 & $5.22-9.90$ & 4.68 & j11_1 & 7.31 & BLT030_1 & 8.67 \\
\hline F & 50.58 & 71.03 & $69.84-72.22$ & 2.38 & R045_1 & 70.12 & Satt510 & 71.41 \\
\hline G & 22.76 & 95.71 & $95.27-96.14$ & 0.87 & Satt472 & 94.84 & Satt191 & 96.57 \\
\hline H & 235.12 & 35.04 & $32.39-37.69$ & 5.30 & A036_1 & 34.29 & Sctt009 & 38.89 \\
\hline H & 235.12 & 57.56 & $55.65-59.48$ & 3.83 & A130_1 & 56.18 & Satt469 & 58.91 \\
\hline H & 235.12 & 68.96 & $68.07-69.84$ & 1.77 & Satt676 & 68.86 & Satt314 & 69.12 \\
\hline H & 235.12 & 81.57 & $79.75-83.40$ & 3.65 & Satt302 & 81.04 & Sat_175 & 83.19 \\
\hline M & 124.22 & 42.75 & $40.85-44.64$ & 3.79 & DOP_H14 & 41.84 & A131_1 & 47.12 \\
\hline M & 124.22 & 56.70 & $55.74-57.66$ & 1.92 & Satt220 & 56.29 & A584_3 & 58.50 \\
\hline M & 124.22 & 60.74 & $60.54-60.94$ & 0.4 & Sat_258 & 60.47 & Satt702 & 61.04 \\
\hline N & 7.28 & 25.60 & $23.53-27.66$ & 4.13 & BLT004_1 & 25.49 & Satt631 & 26.14 \\
\hline
\end{tabular}

Table 18. Meta-analysis results of multiple insect-resistance QTLs 


\subsubsection{Meta-analysis of soybean cyst nematode resistance QTLs}

A meta-analysis was carried out on the consensus QTL sites on 16 QTL clusters (Table 19). 3 true QTLs were related with SCN race1 resistance. The main site was on linkage group G, with flanking markers H3_c6_2 and Satt309 at $2.77 \mathrm{cM}$ and $4.53 \mathrm{cM}$, the C.I. of 1.48cM. One true QTL was simultaneously related with $\mathrm{SCN}$ race2 resistance and $\mathrm{SCN}$ race5 resistance on linkage group B1 with flanking markers R244_1 and AQ851479 at $115.75 \mathrm{cM}$ and $128.66 \mathrm{cM}$, a C.I. of $12.29 \mathrm{cM}$. 7 true QTLs were related with SCN race3 resistance. The main site was on linkage group G with flanking markers Satt309 and B053_1 at 4.53cM and $5.77 \mathrm{cM}$, a C.I. of $1.01 \mathrm{cM}$. 3 true QTLs were related with SCN race4 resistance. The main site was on linkage group A2, with flanking markers Sat_162 and A486_1 at 51.86 cM and $53.16 \mathrm{cM}$, the C.I. of $0.86 \mathrm{cM}$. One true QTL was related with $\mathrm{SCN}$ race14 resistance on linkage group D2 with flanking markers Satt528 and i6_2 at $86.34 \mathrm{cM}$ and 93.92cM, a C.I. of $7.50 \mathrm{cM}$.

\begin{tabular}{|l|c|c|c|c|c|c|c|c|c|}
\hline Trait & LG & $\begin{array}{c}\text { AIC } \\
\text { value }\end{array}$ & $\begin{array}{c}\text { Meta-QTL } \\
\text { position(cM) }\end{array}$ & $\begin{array}{c}\text { 95\% C.I. } \\
(\mathrm{cM})\end{array}$ & $\begin{array}{c}\text { Map } \\
\text { distance }\end{array}$ & L-marker & $\begin{array}{c}\text { L-marker } \\
\text { Position } \\
(\mathrm{cM})\end{array}$ & R-marker & $\begin{array}{c}\text { R-marker } \\
\text { Position } \\
(\mathrm{cM})\end{array}$ \\
\hline Race1 & B1 & 11.72 & 94.66 & $89.08-100.24$ & 11.16 & Satt444 & 85.92 & Sat_123 & 100.88 \\
\hline Race1 & B2 & 27.24 & 57.89 & $54.52-61.26$ & 6.74 & A018_1 & 53.54 & A329_1 & 62.74 \\
\hline Race1 & G & 51.3 & 3.79 & $3.05-4.53$ & 1.48 & H3_c6_2 & 2.77 & Satt309 & 4.53 \\
\hline Race2 & B1 & 19.81 & 121.68 & $115.53-127.82$ & 12.29 & R244_1 & 115.75 & AQ851479 & 128.66 \\
\hline Race3 & A2 & 53.68 & 58.43 & $55.58-61.28$ & 5.70 & Satt187 & 54.92 & A975_2 & 61.29 \\
\hline Race3 & E & 103.64 & 38.31 & $36.47-40.15$ & 3.68 & Satt573 & 35.79 & A386_1 & 39.98 \\
\hline Race3 & G & 334.49 & 5.11 & $4.61-5.62$ & 1.01 & Satt309 & 4.53 & B053_1 & 5.77 \\
\hline Race3 & G & 334.49 & 30.91 & $27.88-33.94$ & 6.06 & Sat_315 & 27.48 & Sat_403 & 34.87 \\
\hline Race3 & G & 334.49 & 72.98 & $70.13-75.84$ & 5.71 & Satt517 & 69.87 & Satt288 & 76.77 \\
\hline Race3 & G & 334.49 & 94.8 & $91.45-98.15$ & 6.70 & A245_2 & 89.97 & H3_54HE_1 & 98.52 \\
\hline Race3 & J & 20.29 & 74.00 & $69.67-78.33$ & 8.66 & Sat_396 & 69.30 & Satt431 & 78.57 \\
\hline Race4 & A2 & 9.90 & 52.30 & $51.87-52.73$ & 0.86 & Sat_162 & 51.86 & A486_1 & 53.16 \\
\hline Race4 & G & 12.36 & 3.87 & $3.20-4.53$ & 1.33 & H3_c6_2 & 2.77 & Satt309 & 4.53 \\
\hline Race4 & H & 18.30 & 59.33 & $54.13-64.53$ & 10.40 & Satt541 & 53.35 & Satt052 & 64.10 \\
\hline Race5 & B1 & 27.13 & 121.68 & $115.53-127.82$ & 12.29 & R244_1 & 115.75 & AQ851479 & 128.66 \\
\hline Race14 & D2 & 22.17 & 90.20 & $86.45-93.95$ & 7.50 & Satt528 & 86.34 & i6_2 & 93.92 \\
\hline
\end{tabular}

Table 19. Meta-analysis results of resistance QTLs to soybean cyst nematode

\subsection{Meta-analysis results of yield QTLs}

\subsubsection{Meta-analysis of 100 -seed weight QTLs}

A meta-analysis was carried out on the consensus QTL sites on 10 QTL clusters (Table 20 ). All the sites were dispersed on 9 linkage groups, only 2 clusters were found on LG B2. The site with the minimal confidence interval was on linkage group D2, with flanking markers Satt458 and Satt135 at $24.52 \mathrm{cM}$ and $26.05 \mathrm{cM}$, the C.I. of $1.52 \mathrm{cM}$.

\subsubsection{Meta-analysis of lodging QTLs}

A meta-analysis was carried out on the consensus QTL sites on 11 QTL clusters (Table 21 ). 5 clusters were found on LG L with the interval of $1.31-6.19 \mathrm{cM}, 7.85-14.03 \mathrm{cM}, 30.58-34.14 \mathrm{cM}$, 
$36.70-41.00 \mathrm{cM}$, and $92.66-111.07 \mathrm{cM}$, the C.I. were $3.55 \mathrm{cM}, 3.82 \mathrm{cM}, 3.12 \mathrm{cM}, 2.78 \mathrm{cM}$, and $17.04 \mathrm{cM}$, individually. The site with the minimal confidence interval was on LG G, with flanking markers Sat_372 and L120_1 at 107.75 cM and $110.45 \mathrm{cM}$, the C.I. was $1.73 \mathrm{cM}$.

\begin{tabular}{|c|c|c|c|c|c|c|c|c|}
\hline LG & $\begin{array}{c}\text { AIC } \\
\text { value }\end{array}$ & $\begin{array}{c}\text { Meta-QTL } \\
\text { position(cM) }\end{array}$ & $\begin{array}{c}\text { 95\% C.I. } \\
(\mathrm{cM})\end{array}$ & $\begin{array}{c}\text { Map } \\
\text { distance }\end{array}$ & L-marker & $\begin{array}{c}\text { L-marker } \\
\text { Position } \\
(\mathrm{cM})\end{array}$ & R-marker & $\begin{array}{c}\text { R-marker } \\
\text { Position } \\
(\mathrm{cM})\end{array}$ \\
\hline B1 & 27.34 & 40.85 & $36.88-44.83$ & 7.95 & Satt251 & 36.48 & Satt197 & 46.39 \\
\hline B2 & 31.71 & 50.36 & $48.53-52.19$ & 3.66 & B142_1 & 43.58 & A108_1 & 53.54 \\
\hline B2 & 31.71 & 65.56 & $60.26-70.86$ & 10.6 & BLT049_2 & 59.82 & G214_4 & 70.88 \\
\hline C2 & 16.89 & 110.19 & $108.64-111.75$ & 3.11 & Satt277 & 107.59 & Satt557 & 112.19 \\
\hline D2 & 6.52 & 25.28 & $24.52-26.04$ & 1.52 & Satt458 & 24.52 & Satt135 & 26.05 \\
\hline H & 16.28 & 50.72 & $47.23-54.22$ & 6.99 & Satt442 & 46.95 & A404T_3 & 55.39 \\
\hline I & 33.65 & 55.1 & $52.27-57.93$ & 5.66 & A955_1 & 51.99 & Satt049 & 58.82 \\
\hline K & 14.51 & 15.68 & $14.33-17.04$ & 2.71 & Satt242 & 14.35 & Sat_119 & 17.11 \\
\hline M & 8.80 & 9.28 & $6.25-12.31$ & 6.06 & Satt636 & 5.00 & Satt201 & 13.56 \\
\hline O & 14.37 & 40.19 & $38.71-41.67$ & 2.96 & Satt653 & 38.10 & Satt347 & 42.30 \\
\hline
\end{tabular}

Table 20. Meta-analysis results of 100-seed weight QTLs

\begin{tabular}{|c|c|c|c|c|c|c|c|c|}
\hline LG & AIC value & $\begin{array}{c}\text { Meta-QTL } \\
\text { position(cM) }\end{array}$ & $\begin{array}{c}95 \% \text { C.I. } \\
(\mathrm{cM})\end{array}$ & $\begin{array}{c}\text { Map } \\
\text { distance }\end{array}$ & L-marker & $\begin{array}{c}\text { L-marker } \\
\text { Position } \\
(\mathrm{cM})\end{array}$ & R-marker & $\begin{array}{c}\text { R-marker } \\
\text { Position } \\
(\mathrm{cM})\end{array}$ \\
\hline B1 & 28.82 & 73.73 & $66.97-80.49$ & 13.52 & BLT043-1 & 66.77 & Satt332 & 80.89 \\
\hline C2 & 29.46 & 112.02 & $110.63-113.4$ & 2.77 & Bng164-1 & 110.14 & Satt319 & 113.42 \\
\hline C2 & 29.46 & 114.1 & $112.71-115.49$ & 2.78 & Satt289 & 112.35 & A397_1 & 116.72 \\
\hline F & 24.04 & 17.5 & $3.50-26.6$ & 23.1 & Satt193 & 3.42 & Satt659 & 26.71 \\
\hline F & 24.04 & 38.9 & $34.90-43.70$ & 8.80 & Satt160 & 33.19 & Satt516 & 44.42 \\
\hline G & 9.99 & 109.86 & $108.47-110.20$ & 1.73 & Sat_372 & 107.75 & L120_1 & 110.45 \\
\hline L & 26.02 & 4.06 & $2.29-5.84$ & 3.55 & Sat_408 & 1.31 & Sle3_4s & 6.19 \\
\hline L & 26.02 & 10.23 & $8.32-12.14$ & 3.82 & BLT010_2 & 7.85 & Satt182 & 14.03 \\
\hline L & 23.53 & 32.22 & $30.66-33.78$ & 3.12 & Satt398 & 30.58 & G214_1 & 34.14 \\
\hline L & 23.53 & 38.16 & $36.77-39.55$ & 2.78 & A023_1 & 36.70 & Satt462 & 41.00 \\
\hline L & 13.09 & 101.7 & $93.18-110.22$ & 17.04 & Satt664 & 92.66 & A802_2 & 111.07 \\
\hline
\end{tabular}

Table 21. Meta-analysis results of lodging QTLs

\subsubsection{Meta-analysis of soybean height QTLs}

A meta-analysis was carried out on the consensus QTL sites on 12 QTL clusters (Table 22 ). On LG B1 and LG K, 3 clusters were found, individually. The site with the minimal confidence interval was on LG K, with flanking markers Satt441 and Satt552 at $41.00 \mathrm{cM}$ and $46.00 \mathrm{cM}$, the C.I. was $0.24 \mathrm{cM}$. 


\begin{tabular}{|c|c|c|c|c|c|c|c|c|}
\hline LG & $\begin{array}{c}\text { AIC } \\
\text { value }\end{array}$ & $\begin{array}{c}\text { Meta-QTL } \\
\text { position(cM) }\end{array}$ & $\begin{array}{c}\text { 95\% C.I. } \\
(\mathrm{cM})\end{array}$ & $\begin{array}{c}\text { Map } \\
\text { distance }\end{array}$ & $\begin{array}{c}\text { L- } \\
\text { marker }\end{array}$ & $\begin{array}{c}\text { L-marker } \\
\text { Position } \\
(\mathrm{cM})\end{array}$ & $\begin{array}{c}\text { R- } \\
\text { marker }\end{array}$ & $\begin{array}{c}\text { R-marker } \\
\text { Position } \\
(\mathrm{cM})\end{array}$ \\
\hline B1 & 105.37 & 32.61 & $30.75-34.47$ & 3.72 & Satt426 & 28.00 & Sat_156 & 35.00 \\
\hline B1 & 105.37 & 56.42 & $54.25-58.58$ & 4.33 & Sat_149 & 54.00 & Satt298 & 65.00 \\
\hline B1 & 105.37 & 87.44 & $81.87-93.01$ & 11.14 & Sat_095 & 81.00 & Satt665 & 96.00 \\
\hline C2 & 18.04 & 105.05 & $102.33-107.78$ & 5.45 & Satt665 & 102.00 & Satt365 & 112.00 \\
\hline D1a & 16.92 & 49.04 & $48.20-49.88$ & 1.68 & Satt342 & 48.00 & Sat_159 & 50.00 \\
\hline F & 27.28 & 111.34 & $105.70-116.98$ & 11.28 & Sat_197 & 104.00 & Satt218 & 118.00 \\
\hline G & 21.53 & 10.08 & $4.12-16.04$ & 11.92 & Sat_168 & 3.90 & Satt217 & 18.00 \\
\hline K & 19.30 & 38.93 & $36.99-40.86$ & 3.87 & Satt137 & 37.00 & Satt178 & 41.00 \\
\hline K & 19.30 & 41.65 & $40.89-42.41$ & 1.52 & Satt178 & 41.00 & Satt555 & 43.00 \\
\hline K & 19.30 & 46.32 & $46.20-46.44$ & 0.24 & Satt441 & 41.00 & Satt552 & 46.00 \\
\hline M & 32.35 & 18.58 & $11.08-26.08$ & 15.00 & Satt590 & 7.80 & Satt567 & 33.00 \\
\hline M & 32.35 & 42.47 & $37.06-47.88$ & 10.82 & Satt540 & 34.00 & Sat_244 & 49.00 \\
\hline
\end{tabular}

Table 22. Meta-analysis results of soybean height QTLs

\subsection{Meta-analysis of soybean growth stage QTLs}

A meta-analysis was carried out on the consensus QTL sites on 7 QTL clusters for R1 period (Table 23), 2 QTL clusters for R8 period(Table 24), and 10 QTL clusters for multiple period(Table 25). Three main sites related with R1 period were on linkage group J, with flanking left markers Satt076, A461_1, and K385_1 at $61.40 \mathrm{cM}, 87.90 \mathrm{cM}$ and $101.30 \mathrm{cM}$, corresponding right markers L050_8, Bng095_1, and Sat_245 at 72.70cM, 100.40cM, and $115.10 \mathrm{cM}$, the C.I. were $10.61 \mathrm{cM}, 8.66 \mathrm{cM}$, and $10.60 \mathrm{cM}$. The site with the minimal confidence interval was on LG C2, with flanking markers Satt365 and Satt658 at $111.70 \mathrm{cM}$ and $113.60 \mathrm{cM}$, the C.I. was $1.63 \mathrm{cM}$.

One site related with R8 period was on LG C2, with flanking markers A397_1 and Sat_263 at $116.70 \mathrm{cM}$ and $118.80 \mathrm{cM}$, the C.I. was $0.90 \mathrm{cM}$. The other site related with R8 period was on LG L, with flanking markers Satt 156 and Satt 678 at $56.10 \mathrm{cM}$ and $70.20 \mathrm{cM}$, the C.I. was $9.64 \mathrm{cM}$.

\begin{tabular}{|c|c|c|c|c|c|c|c|c|}
\hline LG & $\begin{array}{c}\text { AIC } \\
\text { value }\end{array}$ & $\begin{array}{c}\text { Meta-QTL } \\
\text { position(cM) }\end{array}$ & $\begin{array}{c}95 \% \text { C.I. } \\
(\mathrm{cM})\end{array}$ & $\begin{array}{c}\text { Map } \\
\text { distance }\end{array}$ & L-marker & $\begin{array}{c}\text { L-marker } \\
\text { Position } \\
(\mathrm{cM})\end{array}$ & $\begin{array}{c}\text { R-marker } \\
\text { Position } \\
(\mathrm{cM})\end{array}$ \\
\hline C2 & 24.64 & 106.39 & $98.1-107.62$ & 9.52 & Satt363 & 98.10 & Satt277 & 107.60 \\
\hline C2 & 24.64 & 112.75 & $\begin{array}{c}111.98- \\
113.61\end{array}$ & 1.63 & Satt365 & 111.70 & Satt658 & 113.60 \\
\hline M & 20.03 & 33.48 & $32.48-34.47$ & 1.99 & Ts & 30.20 & Satt540 & 35.80 \\
\hline M & 20.23 & 18.58 & $11.08-26.08$ & 15.00 & Satt590 & 7.80 & Mng339_1 & 27.30 \\
\hline L & 47.46 & 67.38 & $62.08-72.69$ & 10.61 & Satt076 & 61.40 & L050_8 & 72.70 \\
\hline L & 47.46 & 93.26 & $88.93-97.59$ & 8.66 & A461_1 & 87.90 & Bng095_1 & 100.40 \\
\hline L & 47.46 & 107.24 & $\begin{array}{c}101.94- \\
112.54\end{array}$ & 10.60 & K385_1 & 101.30 & Sat_245 & 115.10 \\
\hline
\end{tabular}

Table 23. Meta-analysis results of R1 period QTLs 
For multiple periods, some sites were only related with reproductive periods, such as Mul1, Mul2, Mul3, Mul4, Mul9, and Mul10; some site were only related with vegetative periods, such as Mul5 and Mul6; some site were related with both reproductive periods and vegetative periods. Mul3 was very special for its long-term effect on the six of eight reproductive periods.

\begin{tabular}{|c|c|c|c|c|c|c|c|c|}
\hline $\begin{array}{c}\text { L } \\
\text { G }\end{array}$ & $\begin{array}{c}\text { AIC } \\
\text { value }\end{array}$ & $\begin{array}{c}\text { Meta-QTL } \\
\text { position(cM) }\end{array}$ & $\begin{array}{c}\text { 95\% C.I. } \\
(\mathrm{cM})\end{array}$ & $\begin{array}{c}\text { Map } \\
\text { distance }\end{array}$ & L-marker & $\begin{array}{c}\text { L-marker } \\
\text { Position(cM) }\end{array}$ & R-marker & $\begin{array}{c}\text { R-marker } \\
\text { Position(cM) }\end{array}$ \\
\hline C2 & 28.03 & 117.66 & $117.21-118.11$ & 0.90 & A397_1 & 116.70 & Sat_263 & 118.80 \\
\hline L & 16.87 & 64.19 & $59.37-69.01$ & 9.64 & Satt156 & 56.10 & Satt678 & 70.20 \\
\hline
\end{tabular}

Table 24. Meta-analysis results of R8 period QTLs

\begin{tabular}{|c|c|c|c|c|}
\hline $\begin{array}{l}\text { Locus } \\
\text { name }\end{array}$ & LG & Position(cM) & Flanking Marker & Period \\
\hline Mul1 & C1 & 105.06 & Sat_076-K011_3 & R1, R7 \\
\hline Mul2 & C1 & 112.43 & Satt365-Satt658 & R1, R8 \\
\hline Mul3 & D1a & 55.89 & Satt515-Sat_201 & R1, R2, R3, R4, R5, R7 \\
\hline Mul4 & D1a & 63.76 & Satt343-Satt507 & R2, R4, R6, R8 \\
\hline Mul5 & D1b & 67.09 & A605_1-Sat_423 & V8, V9 \\
\hline Mul6 & D1b & 73.41 & Satt290 & V11, V12 \\
\hline Mul7 & D1b & 78.02 & Bng047_1-Sat_169 & V13, V14, R3, R4, R5 \\
\hline Mul8 & D1b & 80.84 & Satt644-Satt041 & V18, R1, R3 \\
\hline Mul9 & F & 26.98 & Satt659-Satt206 & R1, R3, R7 \\
\hline Mul10 & J & 43.01 & Satt380 & R1, R3, R7 \\
\hline
\end{tabular}

Table 25. Meta-analysis results of multiple period QTLs

\section{Discussion}

Soymap2, the reference map

A new public map, soymap2, was constructed by Song (2004). Five soybean genetic maps, including molecular genetic maps of two F2 populations, A81-356022 $\times$ PI468916 and Clark $\times$ Harosoy, and three RIL populations, Minsoy $\times$ Noir1, Minsoy $\times$ Archer, and RILs of Noir $1 \times$ Archer, were integrated. The public map contains 20 LGs and 1,849 markers, including 709 restriction fragment length polymorphism (RFLP) markers, 1,015 Simple Sequence Repeat (SSR) markers, 73 random amplified polymorphic DNA (RAPD) markers, six amplified fragment length polymorphism (AFLP) markers, and 46 markers of other types. This integrated map shows a very high density of SSR and RFLP markers, commonly used to map QTLs. Thus, QTLs from these maps could be easily projected onto the public map.

Using of meta-analysis in MAS

MAS is an important strategy for crop improvement. Recently, MAS has been successfully used to increase the quality and yield of wheat (Romagosa. 1999) and rice (Wang. 2004). However, due to its validity, cost, and the low number of markers, MAS has not been widely applied in crops. The accuracy of mapping QTLs decides the efficiency of gene discovery and cloning.

Meta-analysis is an important tool in linkage analysis, optimize QTL, shrink the confidence interval, and improve the accuracy and validity of QTL position (Löffler, 2009), and is of 
particular relevance for the validation of known QTL. QTL location is affected by many factors, including genetic background, population size and analytical method, so a single study can only be taken as suggestive, unless it is based on a large enough set of experiments. Where the $\mathrm{CI}$ is large, it is difficult to distinguish between the presence of a single locus and the presence of two (or more) loci. The meta-analysis approach, as developed by Goffinet and Gerber (2000), however does provide a means to alleviate the extent of this uncertainty, since it improves the capacity to identify the true number of QTL present, and the precision of their location by reducing their associated CI. QTL associated with early maturity in bread wheat have recently been identified using a meta-analysisbased approach (Hanocq, 2007), and similarly, resistance to gray leaf spot in maize has been genetically defined by the integration of $>50$ QTL (Shi, 2007). The proportion of the phenotypic variance explained by a given QTL (its $\mathrm{R}^{2}$ value) is the most important parameter in deciding whether marker assistance can be more efficient than conventional phenotypic selection alone (Bernardo 2001; Bernardo and Charcosset 2006).

The molecular markers in the consensus QTL could be used for individual selection in the original mapping population. In addition, some important intervals could be enhanced by backcrossing for QTL fine mapping. However, some key aspects of MAS still require improvement. The first is how to evaluate the contribution ratio of the allele for a special locus. For some populations, the allele is major, but for others it is minor. The second aspect is how to build a practical model for MAS or molecular design, which is important for the application of markers. We hope that the meta-analysis reported here will guide the choice of QTL targeted for marker assisted selection, and it was the foundation for the process of acquiring QTL-related genes in soybean.

Use of bioinformatics tools in mining candidate genes

With the advent of soybean genomic information and bioinformatics tools, finding consensus QTL intervals in the corresponding physical map is easier, particularly for mining candidate genes ( $\mathrm{Lv}$ et al. 2008). Bioinformatics tools are important in the process leading from QTL to the quantitative trait gene, or QTG. Wang and Paigen (2002) found that 18 of the 22 human high-density lipoprotein-cholesterol (HDL-C) QTLs were within the murine HDL-C QTLs, suggesting that murine QTLs for HDL-C levels may have homologous locations in humans and that their underlying genes may be appropriate for testing in humans. GENSCAN is a general-purpose gene identification program that analyzes genomic DNA sequences from a variety of organisms, including humans, other vertebrates, invertebrates, and plants. The InterProScan server analyzes sequences (cDNA, protein) with respect to international GO terms. In this study, traditional QTLs were integrated, and some important genes related to the important agronomic traits could be mined in the future.

\section{Conclusion}

In this chapter, the QTLs of 12 important agronomic traits in soybean were integrated by meta-analysis. For seed quality traits, 25 consensus QTLs of oil content were extracted from 130 initial research QTLs, 23 consensus QTLs of protein concentration from 107 QTLs, 23 consensus QTLs of fatty acid from 83 QTLs, 111 consensus QTLs of amino acid content from 111 QTLs, 10 consensus QTLs of isoflavone content from 70 QTLs. For biotic stress resistance traits, 23 consensus QTLs of fungal disease resistance were extracted from 107 initial research QTLs, 14 consensus QTLs of insect resistance from 81 QTLs, 16 consensus 
QTLs of soybean cyst nematode resistance from 135 QTLs. For yield trait, 6 consensus QTLs of 100-seed weight were extracted from 78 initial research QTLs, 11 consensus QTLs of lodging from 59 QTLs, 12 consensus QTLs of plant height from 93 QTLs. For soybean growth stages, 7 consensus QTLs were extracted from 98 initial research QTLs

\section{References}

Alexandre, G. (2008). Molecular mapping of soybean rust (Phakopsora pachyrhizi) resistance genes-discovery of a novel locus and alleles. Theoretical and Applied Genetics, 117, 545-553. ISSN: 0040-5752

Andrea, J. (2007). Molecular analysis of soybean lines with low palmitic acid content in the seed oil. Crop Science, 47, 304-310. ISSN: 0011-183X

Arahana, SV. (2001). Identification of QTLs for resistance to Sclerotinia sclerotiorum in soybean. Crop Science, 41, 180-188. ISSN: 0011-183X

Austeclinio, LFN. (2007). Mapping and confirmation of a new sudden death syndrome resistance QTL on linkage group D2 from the soybean genotypes PI 567374 and 'Ripley'. Molecular Breeding, 20, 53-62. ISSN 1380-3743

Bachman, M S. (2001). Molecular markers linked to brown stem rot resistance genes, Rbs1 and Rbs2, in soybean. Crop Science, 41, 527-535. ISSN: 0011-183X

Bell-Johnson, B. (1999). Selecting soybean cultivars for dual resistance to soybean cyst nematode and sudden death syndrome using two DNA markers. Crop Science, 39, 982-987. ISSN: 0011-183X

Berger, GU. (1999). An RFLP marker associated with resistance to phomopsis seed decay in soybean PI 417479. Crop Science, 39, 800-805. ISSN: 0011-183X

Bernardo, R. (2001). What if we knew all the genes for a quantitative trait in hybrid crops? Crop Science, 41, 1-4. ISSN: 0011-183X

Bernardo, R. (2006). Usefulness of gene information in marker-assisted recurrent selection: a simulation appraisal. Crop Science, 46, 614-621. ISSN: 0011-183X

Boerma, HR. Discovery and utilization of QTLs for insect resistance in soybean. Genetica, 2005, 123, 181-189. ISSN: 0016-6707

Brucker, E. Rhg1 alleles from soybean PI 437654 and PI 88788 respond differentially to isolates of Heterodera glycines in the greenhouse. Theoretical and Applied Genetics, 2005, 111, 1, 44-49. ISSN: 0040-5752

Brummer, EC. (1997). Mapping QTL for seed protein and oil content in eight soybean populations. Crop Science, 37, 370-378. ISSN: 0011-183X

Burnham, KD. (2003). Rps8, a new locus in soybean for resistance to Phytophthora sojae. Crop Science, 43, 101-105. ISSN: 0011-183X

Chase, K. (2001). Soybean response to water: a QTL analysis of drought tolerance. Crop Science, 41:493-509. ISSN: 0011-183X

Chen, QS. (2007). QTL mapping of some agronomic traits of soybean. Scientia Agricultura Sinica, 6, 4, 399-405. ISSN 0578-1752

Chung, J. (2003). The seed protein, oil, and yield QTL on soybean linkage group I. Crop Science, 43, 3, 1053-1067. ISSN: 0011-183X

Concibido, VC. (1996). RFLP mapping and marker-assisted selection of soybean cyst nematode resistance in PI 209332. Crop Science, 36, 6, 1643-1650. ISSN: 0011-183X

Concibido, VC. (1997). Genome mapping of soybean cyst nematode resistance genes in 'Peking', PI 90763, and PI 88788 using DNA markers. Crop Science, 37, 10, 258-264. ISSN: 0011-183X 
Csanádi, G. (2001). Seed quality QTLs identified in a molecular map of early maturing soybean. Theoretical and Applied Genetics, 103, 912-919. ISSN: 0040-5752

Danielle, CGS. (2008). Molecular mapping of two loci that confer resistance to Asian rust in soybean. Theoretical and Applied Genetics, 117, 57-63. ISSN: 0040-5752

Diers, BW. (1992). RFLP analysis of soybean seed protein and oil content. Theoretical and Applied Genetics, 83, 608- 612. ISSN: 0040-5752

Ferdous, SA. (2006). QTL analysis of resistance to soybean cyst nematode race 3 in soybean cultivar Toyomusume. Breeding Science, 56, 2, 155-163. ISSN 1344-7610

$\mathrm{Fu}$, Sanxiong. (2007). Mapping insect resistance QTLs of soybean with RIL population. Hereditas, 29, 9, 1139-1143. ISSN 1673-8527

Funatsuki, H. (2005). Mapping of QTL associated with chilling tolerance during reproductive growth in soybean. Theoretical and Applied Genetics, 111, 851-861. ISSN: 0040-5752

Gai, JY. (2007). A comparative study on segregation analysis and QTL mapping of quantitative traits in plants-with a case in soybean. Frontiers of Agriculture in China, 1, 1, 1-7. ISSN 1673-7334

Glover, KD. (2004). Near isogenic lines confirm a soybean cyst nematode resistance gene from PI 88788 on Linkage Group J. Crop Science, 44, 3, 936-941. ISSN: 0011-183X

Goffinet, B. (2000). Quantitative trait loci: a meta-analysis. Genetics, 155, 463-473. ISSN: 00166731

Guo, B. (2005). Identification of QTLs associated with resistance to soybean cyst nematode races 2, 3 and 5 in soybean PI 90763. Theoretical and Applied Genetics, 111, 5, 965971. ISSN: 0040-5752

Guo, B. (2006). Quantitative trait loci underlying resistance to three soybean cyst nematode populations in soybean PI 404198A. Crop Science, 46, 1, 224-233. ISSN: 0011-183X

Guo, XM. (2008). Genetic mapping of QTLs underlying partial resistance to Sclerotinia sclerotiorum in Soybean PI 391589A and PI 391589B. Crop Science, 48, 1129-1139. ISSN: 0011-183X

Guzman, PS. (2007). QTL associated with yield in three backcross-derived populations of soybean. Crop Science, 47, 111-122. ISSN: 0011-183X

Han, YP. (2008). Mapping QTL tolerance to Phytophthora root rot in soybean using microsatellite and RAPD/SCAR derived markers. Euphytica, 162, 231-239. ISSN 0014-2336

Hanocq, E. (2007). Most significant genome regions involved in the control of earliness traits in bread wheat, as revealed by QTL meta-analysis. Theoretical and Applied Genetics, 114, 569-584. ISSN: 0040-5752

Heer, JA. (1998). Molecular markers for resistance to Heterodera glycines in advanced soybean germplasm. Molecular Breeding, 4, 4, 359-367. ISSN 1380-3743

Huang, ZW. (2008). Lodging resistance indices and related QTLs in soybean. Acta Agronomica Sinica, 34, 4, 605 611. ISSN 0496-3490

Hyten, DL. (2004). Seed quality QTL in a prominent soybean population. Theoretical and Applied Genetics, 109, 552-561. ISSN: 0040-5752

Hyten, DL. (2007). Map location of the Rpp1 locus that confers resistance to soybean rust in soybean. Crop Science, 47, 837-840. ISSN: 0011-183X

Iqbal, MJ. (2001). Microsatellite markers identify three additional quantitative trait loci for resistance to soybean sudden-death syndrome (SDS) in Essex $\times$ Forrest RILs. Theoretical and Applied Genetics, 102, 187-192. ISSN: 0040-5752 
Kabelka, EA. (2004). Putative alleles for increased yield from soybean plant introduction. Crop Science, 44, 784-791. ISSN: 0011-183X

Kabelka, EA. (2005). Localization of two loci that confer resistance to soybean cyst nematode from Glycine soja PI 468916. Crop Science, 45, 6, 2473-2481. ISSN: 0011-183X

Kassem, MA. (2004). Definition of soybean genomic regions that control seed phytoestrogen amounts. Journal of Biomedicine and Biotechnology, 1, 1, 52-60. ISSN 1110-7243

Kassem, MA. (2006). An updated 'Essex' by 'Forrest' linkage map and first composite interval map of QTL underlying six soybean traits. Theoretical and Applied Genetics, 113, 1015 1026. ISSN: 0040-5752

Kazi, S. (2008). Separate loci underlie resistance to root infection and leaf scorch during soybean sudden death syndrome. Theoretical and Applied Genetics, 116, 967-977. ISSN: 0040-5752

Kunihiko, K. (2005). QTL mapping of antibiosis resistance to common cutworm (Spodoptera litura Fabricius) in soybean. Crop Science, 45, 2044-2048. ISSN: 0011-183X

Kunihiko, K. (2007). Quantitative trait loci mapping of pubescence density and flowering time of insect-resistant soybean (Glycine max L. Merr.). Genetics and Molecular Biology, 30, 3, 635-639. ISSN 1415-4757

Lee, SH. (1996). RFLP loci associated with soybean seed protein and oil content across populations and locations. Theoretical and Applied Genetics, 93, 649-657. ISSN: 0040-5752

Lewers, KS. (1999). Detection of linked QTL for soybean brown stem rot resistance in 'BSR 101 ' as expressed in a growth chamber environment. Molecular Breeding, 5, 33-42. ISSN 1380-3743

Li, DD. (2008). Soybean QTL for yield and yield components associated with Glycine soja alleles. Crop Science, 48: 571-581. ISSN: 0011-183X

Li, Y. (2007). Soybean aphid resistance genes in the soybean cultivars Dowling and Jackson map to linkage group M. Molecular Breeding, 19, 25-34. ISSN 1380-3743

$\mathrm{Li}, \mathrm{ZL}$. (2002). Molecular mapping genes conditioning reduced palmitic acid content in N872122-4 soybean polymorphism. Crop Science, 42, 373-378. ISSN: 0011-183X

Liu, H. (2005). Inheritance analysis and mapping QTLs related to cotton worm resistance in soybeans. Scientia Agricultura Sinica, 38, 7, 1369-1372. ISSN 0496-3490

Löffler, M. (2009). Revealing the genetic architecture of FHB resistance in hexaploid wheat (Triticum aestivum L.) by QTL meta-analysis. Molecular Breeding, 23, 473-488. ISSN 1380-3743

$\mathrm{Lv}$, XL. (2008). Comparative QTL mapping of resistance to sugarcane mosaic virus in maize based on bioinformatics. Hereditas, 30, 1, 101-108. ISSN 1673-8527

Mahalingam, R. (1995). DNA markers for resistance to Heterodera glycines race-3 in soybean cultivar 'Peking' Breed. Crop Science, 35, 2, 435-443. ISSN: 0011-183X

Mansur, LM. (1993). Interval mapping of quantitative trait loci for reproductive, morphological, and seed traits of soybean(Glycine max L.). Theoretical and Applied Genetics, 86, 907-913. ISSN: 0040-5752

Mansur, LM. (1996). Genetic mapping of agronomic traits using recombinant inbred lines of soybean. Crop Science, 36, 5, 1327-1336. ISSN: 0011-183X

Maria, J. (2008). Molecular mapping and confirmation of QTLs associated with oleic acid content in N00-3350 Soybean. Crop Science, 48, 2223-2234. ISSN: 0011-183X

Masayuki, Shibata. (2008) Genetic relationship between lipid content and linolenic acid concentration In soybean seeds. Breeding science, 58, 361-366. ISSN 1344-7610 
Meksem, K. (1999). Clustering among loci underlying soybean resistance to Fusarium solani, SDS and SCN in near-isogenic lines. Theoretical and Applied Genetics, 9, 11311142. ISSN: 0040-5752

Meksem, K. (2001a). Genomic regions that underlie soybean seed isoflavone content. Journal of Biomedicine and Biotechnology, 1, 1, 38-44. ISSN 1110-7243

Meksem, K. (2001b). 'Forrest' resistance to the soybean cyst nematode is bigenic: saturation mapping of the Rhg1 and Rhg4 loci. Theoretical and Applied Genetics, 103, 5, 710717. ISSN: 0040-5752

Meng, X. (2003). QTL mapping genes conferring resistance to race 4 of soybean cyst nematode in soybean ZDD2315 (Glycine max (L) Merr.) based on public molecular genetic linkage map. Molecular Plant Breeding, 1, 1, 6-21. ISSN 1672-416X

Mian, MAR. (1999). Molecular mapping of the Rcs3 gene for resistance to frogeye leaf spot in soybean. Crop Science, 39, 1687-1691. ISSN: 0011-183X

Mian, RMA. (2008). Genetic linkage mapping of the soybean aphid resistance gene in PI 243540. Theoretical and Applied Genetics, 117, 955-962. ISSN: 0040-5752

Monteros, MJ. (2007). Mapping and confirmation of the 'Hyuuga' red-brown lesion resistance gene for Asian soybean rust. Crop Science, 47, 829-836. ISSN: 0011-183X

Naoki, Y. (2001). An informative linkage map of soybean reveals QTLs for flowering time, leaflet morphology and regions of segregation distortion. DNA Research, 8, 61-72. ISSN 1340-2838

Narvel, JM. (2001). A retrospective DNA marker assessment of the development of insect resistant soybean. Crop Science, 41, 6, 1931-1939. ISSN: 0011-183X

Njiti, VN. (2002). Common loci underlie field resistance to soybean sudden death syndrome in Forrest, Pyramid, Essex, and Douglas. Theoretical and Applied Genetics, 104, 294-300. ISSN: 0040-5752

Orf, JH. (1999).Genetics of soybean agronomic traits: I. Comparison of three related recombinant inbred populations. Crop Science, 39, 6, 1642-1651. ISSN: 0011-183X

Panthee, DR. (2005). Quantitative Trait Loci for Seed Protein and Oil Concentration, and Seed Size in Soybean. Crop Science, 45, 2015-2022. ISSN: 0011-183X

Panthee, DR. (2006a). Modifier QTL for fatty acid composition in soybean oil. Euphytica, 152, 67-73. ISSN 0014-2336

Panthee, DR. (2006b). Genomic regions associated with amino acids composition in soybean seeds. Molecular Breeding, 17, 79-89. ISSN 1380-3743

Panthee, DR. (2006c). Quantitative trait loci controlling sulfur containing amino acids, methionine and cysteine, in soybean seeds. Theoretical and Applied Genetics, 112, 546-553. ISSN: 0040-5752

Patzoldt, ME. (2005a). Characterization of resistance to brown stem rot of soybean in five accessions from central China. Crop Science, 45, 1092-1095. ISSN: 0011-183X

Patzoldt, ME. (2005b). Localization of a quantitative trait locus providing brown stem rot resistance in the soybean cultivar bell. Crop Science, 45, 1241-1248. ISSN: 0011-183X

Prabhu, RR. (1999). Selecting soybean cultivars for dual resistance to soybean cyst nematode and sudden death syndrome using two DNA markers. Crop Science, 39, 4, 982-987. ISSN: 0011-183X

Qiu, BX. (1999). RFLP markers associated with soybean cyst nematode resistance and seed composition in a 'Peking' x 'Essex' population. Theoretical and Applied Genetics, 98, 356-364. ISSN: 0040-5752 
Rector, BG. (1998). Identification of molecular markers linked to quantitative trait loci for soybean resistance to corn earworm. Theoretical and Applied Genetics, 96, 786-790. ISSN: 0040-5752

Rector, BG. (2000). Quantitative trait loci for antibiosis resistance to corn earworm in soybean. Crop Science, 40, 1, 233-238. ISSN: 0011-183X

Romagosa, I. (1999). Verification of yield QTL through molecular marker assisted selection responses in a barley cross. Molecular Breeding, 5, 143-152. ISSN 1380-3743

Schuster, I. (2001). Identification of a new major QTL associated with resistance to soybean cyst nematode. Theoretical and Applied Genetics, 2001, 102(1): 91-96. ISSN: 00405752

Sebolt, AM. (2000). Analysis of a quantitative trait locus allele from wild soybean that increases seed protein concentration in soybean. Crop Science, 40, 5, 1438-1444. ISSN: 0011-183X

Shan, DP. (2008). Epistatic Effects of QTLs and QE Interaction Effects on Oil Content in Soybean. Acta Agronomica Sinica, 34, 6, 952-957. ISSN 0496-3490

Shan, DP. (2009). Epistatic effects of QTLs and QE Interaction effects on protein content in soybean. Acta Agronomica Sinica, 35, 1, 41-47. ISSN 0496-3490

Shi, LY. (2007). Comparative QTL mapping of resistance to gray leaf spot in maize based on bioinformatics. Scientia Agricultura Sinica, 6, 12, 1411-1419. ISSN 0578-1752

Song, QJ. (2004). A new integrated genetic linkage map of the soybean. Theoretical and Applied Genetics, 109, 122-128. ISSN: 0040-5752

Specht, JE. (2001). Soybean response to water: a QTL analysis of drought tolerance. Crop Science, 41, 2, 493-509. ISSN: 0011-183X

Spencer, M. (2004). Molecular markers associated with linolenic acid content in soybean. Journal of the American Oil Chemists' Society, 81, 559-562. ISSN: 0003-021X

Tajuddin, T. (2003). Analysis of quantitative trait loci for protein and lipid contents in soybean seeds using recombinant inbred lines. Breeding Science, 53, 133-140. ISSN 1344-7610

Tasma, M. (2001). Mapping genetic loci for flowering time, maturity, and photoperiod insensitivity in soybean. Molecular Breeding, 8, 25-35. ISSN 1380-3743

Terry, LI. (1999). Insect resistance in recombinant inbred soybean lines derived from nonresistant parents. Entomologia Experimentalis et Applicata, 91, 465-476. ISSN: 0013-8703

Terry, LI. (2000). Soybean quantitative trait loci for resistance to insects. Crop Science, 40, 2, 375-382. ISSN: 0011-183X

Vierling, RA. (1996). Association of RFLP markers with loci conferring broad-based resistance to the soybean cyst nematode (Heterodera glycines). Theoretical and Applied Genetics, 92, 1, 83-86. ISSN: 0040-5752

Walker, DR. (2004). A QTL that enhances and broadens Bt insect resistance in soybean. Theoretical and Applied Genetics, 109, 5, 1051-1057. ISSN: 0040-5752

Wang, D. (2001). Loci underlying resistance to Race 3 of soybean cyst nematode in Glycine soja plant introduction 468916. Theoretical and Applied Genetics, 103, 4, 561-566. ISSN: 0040-5752

Wang, D. (2004). Identification of putative QTL that underlie yield in interspecific soybean backcross populations. Theoretical and Applied Genetics, 108, 458-467. ISSN: 00405752

Wang, H. (2007). A Sensitive molecular marker SSR associated with resistant gene to Heterodera Glycines. Soybean science, 26, 2, 204-207. ISSN 1000-9841 
Wang, XS. (2002). Quantitative trait loci and candidate genes regulating HDL cholesterol: a murine chromosome map. Arteriosclerosis, Thrombosis, and Vascular Biology, 22, 9, 1390-1401. ISSN 1049-8834

Wang, XZ. (2007). QTL analysis of seed and pod traits in soybean RIL population. Acta Agronomica Sinica, 33, 3, 441-448. ISSN 0496-3490

Wang, XZ. (2008). Map construction and QTL analysis of oil content in soybean. Chinese Journal Of Oil Crop Science, 30, 3, 272-278. ISSN 1007-9084

Wang, YG. (2004). Molecular marker assisted selection for yield enhancing genes in the progeny of Minghui63 $\times$ Orufipogon. Scientia Agricultura Sinica, 103, 75-83. ISSN 0578-1752

Weng, CH. (2007). A quantitative trait locus influencing tolerance to Phytophthora root rot in the soybean cultivar 'Conrad'. Euphytica, 158, 81-86. ISSN 0014-2336

$\mathrm{Wu}, \mathrm{XL}$. (2001). QTL mapping of some agronomic traits of soybean. Journal of Genetics and Genomics, 28, 10, 947-955. ISSN: 1673-8527

Xin, DW. (2007). Analysis of quantitative trait loci underlying the period of vegetative growth stages in soybean (Glycine max [L.] Merr.). Molecular Plant Breeding, 5, 5, 639-647. ISSN 1672-416X

Xin, DW. (2008). Analysis of quantitative trait loci underlying the period of reproductive growth stages in soybean (Glycine max [L.] Merr.). Euphytica, 162, 2, 155-165. ISSN 0014-2336

Xu, P. (2007). QTL positioning of oil content in soybean. Hereditas, 29, 1, 92-96. ISSN 1673-8527

Yang, Z. (2004). Construction of genetic map and QTL analysis for some agronomic traits in soybean. Acta Agronomica Sinica, 30, 413-418. ISSN 0496-3490

Yarmilla, Reinprecht. (2006). Seed and agronomic QTL in low linolenic acisd lipoxygenasefree soybean (Glycine max (L.)Merrill ) germplasms. Genome, 49, 1510-1527. ISSN 0831-2796

Yue, P. (2001a). Mapping resistance to multiple races of Heterodera glycines in soybean PI 89772. Crop Science, 41, 5, 1589-1595. ISSN: 0011-183X

Yue, P. (2001b). Molecular characterization of resistance to Heterodera glycines in soybean PI 438489B. Theoretical and Applied Genetics, 102, 6-7, 921-928. ISSN: 0040-5752

Zhang, GR. (2009). Molecular mapping of soybean aphid resistance genes in PI 567541B. Theoretical and Applied Genetics, 118, 473-482. ISSN: 0040-5752

Zhang, WH. (2004). Analysis of resistant gene against Cercospora sojina Race 1 in soybean with SSR markers. Soybean Science, 23, 169-173. ISSN 1000-9841

Zhang, WK. (2004). QTL mapping of ten agronomic traits on the soybean (Glycine max L. Merr.) genetic map and their association with EST markers. Theoretical and Applied Genetics, 108, 1131-1139. ISSN: 0040-5752

Zhang, ZC. (2004). QTL mapping seed oil and protein content of soybean. Soybean Science, $23,2,81-85$. ISSN 1000-9841

Zhao, G. (2005). Inheritance and genetic mapping of resistance to rhizoctonia root and hypocotyl rot in soybean. Crop Science, 45, 1441-1447. ISSN: 0011-183X

Zhao, GY. (2008). Identification of QTL underlying the resistance of soybean to pod borer, Leguminivora glycinivorella (Mats.) obraztsov, and correlations with plant, pod and seed traits. Euphytica, 164, 275-282. ISSN 0014-2336

Zheng, Yongzhan. (2006). QTL Mapping for fat and fatty acid composition contents in soybean. Acta Agronomica Sinica, 32, 12, 1823-1830. ISSN 0496-3490

Zhou, R. (2009). QTL analysis of lodging and related traits in soybean. Acta Agronomica Sinica, 35, 1, 57-65. ISSN 0496-3490 


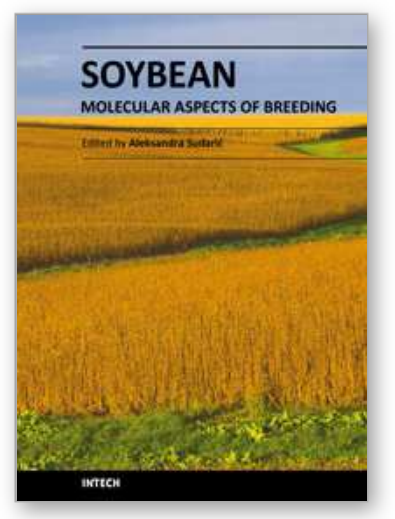

\author{
Soybean - Molecular Aspects of Breeding \\ Edited by Dr. Aleksandra Sudaric
}

ISBN 978-953-307-240-1

Hard cover, 514 pages

Publisher InTech

Published online 11, April, 2011

Published in print edition April, 2011

The book Soybean: Molecular Aspects of Breeding focuses on recent progress in our understanding of the genetics and molecular biology of soybean and provides a broad review of the subject, from genome diversity to transformation and integration of desired genes using current technologies. This book is divided into four parts (Molecular Biology and Biotechnology, Breeding for Abiotic Stress, Breeding for Biotic Stress, Recent Technology) and contains 22 chapters.

\title{
How to reference
}

In order to correctly reference this scholarly work, feel free to copy and paste the following:

Guohua Hu, Qingshan Chen, Chunyan Liu, Hongwei Jiang, Jialin Wang and Zhaoming Qi (2011). Integration of Major QTLs of Important Agronomic Traits in Soybean, Soybean - Molecular Aspects of Breeding, Dr. Aleksandra Sudaric (Ed.), ISBN: 978-953-307-240-1, InTech, Available from:

http://www.intechopen.com/books/soybean-molecular-aspects-of-breeding/integration-of-major-qtls-ofimportant-agronomic-traits-in-soybean

\section{INTECH}

open science | open minds

\section{InTech Europe}

University Campus STeP Ri

Slavka Krautzeka 83/A

51000 Rijeka, Croatia

Phone: +385 (51) 770447

Fax: +385 (51) 686166

www.intechopen.com

\section{InTech China}

Unit 405, Office Block, Hotel Equatorial Shanghai

No.65, Yan An Road (West), Shanghai, 200040, China

中国上海市延安西路65号上海国际贵都大饭店办公楼 405 单元

Phone: +86-21-62489820

Fax: $+86-21-62489821$ 
(C) 2011 The Author(s). Licensee IntechOpen. This chapter is distributed under the terms of the Creative Commons Attribution-NonCommercialShareAlike-3.0 License, which permits use, distribution and reproduction for non-commercial purposes, provided the original is properly cited and derivative works building on this content are distributed under the same license. 